\title{
Indian and Persian swordsmanship: A Comparative Analysis
}

\author{
Aleksey KUROCHKIN ${ }^{*}$ \& Manouchehr Moshtagh KHORASANI ${ }^{*}$ \\ 1 Independent Researcher (Russian Federation) \\ 2 Independent Researcher (Germany)
}

Recepción: 11/06/2014; Aceptación: 20/06/2015; Publicación: 28/06/2015.

\begin{abstract}
The existing cultural interconnection between Iran and North India, which existed and developed over a long period of time, is known today as "Indo-Iranian" or "Indo-Persian", which could be applied to the region, culture, literature, weapons and other spheres of intercultural interference. The cultural cooperation between these two countries was bilateral and marked by trade routes. This paper is aimed at analyzing the interrelation, similarities and differences between the martial and military cultures of India and Persia. More precisely, the article describes the field of individual training in military skills, methods of their acquisition and retention, as well as the usage of the related weapons. For this purpose, we carried out a comparative analysis based on historical sources as well as on contemporary literature on the topic. First, the paper focuses on general principles and weapon traditions in both cultures. The next section deals with a description of some techniques of Persian swordsmanship as described in Persian manuscripts. The next part describes some aspects of Indian swordsmanship. Then the last part describes some similarities and differences related to techniques of swordsmanship in both traditions. However, one should stress that although there are many extant Persian manuscripts on warfare and fighting techniques, no related Indian manuscripts have been found so far. This article is only at an intial stage of research.
\end{abstract}

Palabras clave: Martial Arts; India; Persia; sword; Indian culture; Persian culture and language; Indian swordsmanship; Persian swordsmanship.

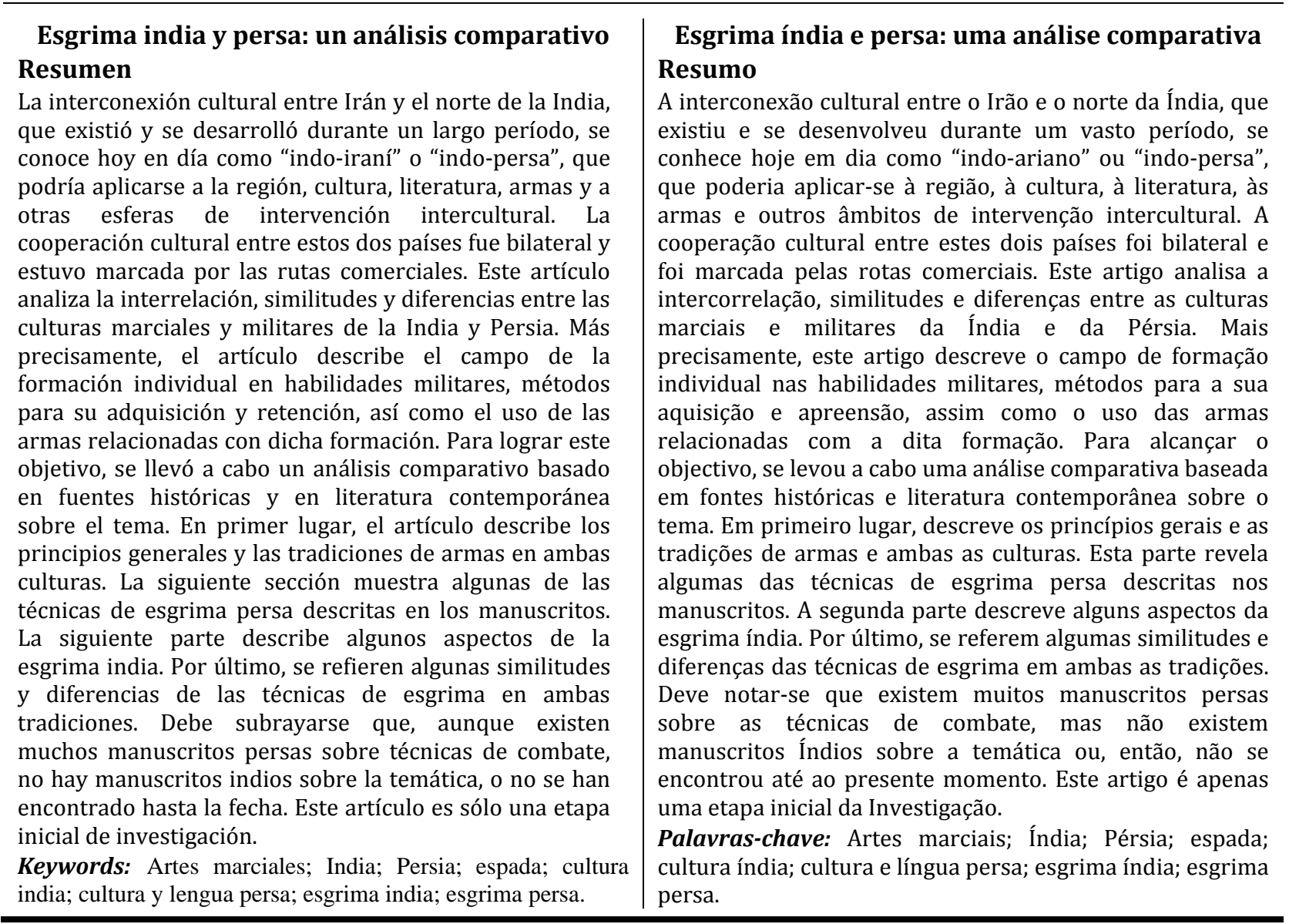

*E-mail: kay al@mail.ru; manouchehr@moshtaghkhorasani.com. 


\section{Introducción}

India and Iran shared close and obvious common interests regarding conquests and invasions. Even Darius the Great conquered territories within the borders of the future Punjab and Sind regions. Muslim expansion, which began with Arab invasions in the 6th century and continued in the 11th century by Turkic conquerors led to the establishment of the first Muslim state on the territory of India at the beginning of the 13th century. The time limits of this period were parallel to the Iranian cultural renaissance and the spread of Persian language in the Safavid empire. One of the key areas of intercultural interaction was the field of weapons and swordsmanship techniques. Starting from the $13^{\text {th }}$ century Persian cultural influence rapidly spread throughout the Muslim world. The conquerors of North India had already adopted the Persian culture (Bosworth, 2004, p. 297). Unlike other conquerors, the Muslim conquerors of India did not dissolve into the culture of the conquered country, but they brought their own political and military system, lifestyle, trends of social relations and culture. This was not the case in Iran, as all conquerors adopted and were heavily influenced by Persian culture (Frye, 1989, p. 236). Another important factor was that the people were hard to control because of their mobility and porousness of the region (see Kolff, 2002; Nitin, 2008, pp. 1-33). Taking all these factors into consideration, one should note that North India possessed necessary conditions for adopting Persian culture in all areas of life at the time of the Moghul invasion. If the Baburnāme [Book of Bābur] was written in the native language of the Turkic conquerors (with some parts written in Persian poems), the Akbarnāme [Book of Akbar] in its turn was entirely composed in Persian. At the same time, the cultural cooperation was not coerced by taking unilateral measures. Moreover, the acceptance of many aspects of Persian culture occurred through substitution of similar Indian traditions or through a compromise as in case of Urdu language genesis, which was an organic combination of linguistic elements from Indian dialects with the Persian language. In case of replacement of autochthonous linguistic elements from Indian dialects by those brought by the Persian language, the last elements gradually started to be perceived as originally Indian, precisely because of the conformity and even similarity of these elements. For example the term for traditional Indian wrestling "kushti" is originated from Persian word "košti" (see Khorasani, 2010a, p. 217) while Indian wrestling was called "malla". Perhaps, in some cases there was only a replacement of a name or a term due to the predominance of the Persian language evidenced by an extant body of texts written in Persian. At the same time there were still some completely indigenous elements, which had not been exposed to an external influence.

\section{General principles and weapon traditions}

It is very hard to draw a parallel between Persian and North Indian fighting traditions at the present time. Although it is possible to explore Persian traditions based on numerous extant written sources, one can only rely on partially preserved (perhaps even partially modified) physical martial practices while studying North Indian traditions. It is obvious that information which can be discovered from the manuscripts and descriptions explain firstly specific techniques, which are possible to be deduced as part of a complete warrior training curriculum. It is extremely hard to track methodological components and details of a specific warrior training program, per se. There are extant methodological descriptions and main training principles in case of North Indian practices, but understanding and application of them as a specific set of techniques is lost.

Considering all above-mentioned circumstances, it would be useful for those who are interested in Indian fighting techniques to become aware of real warrior techniques and traditions from Persian warrior manuscripts, and, perhaps, to compensate the lack of this information on North Indian traditions, or to draw parallels and understand what results the basic training principles and methods can lead to. It could be that followers of the Persian fighting arts and techniques will be curious to know the extent of the methodological process in North Indian traditions. An important factor which is also the common denominator of the explored traditions is the similarity of the weapons used within the framework of each tradition. Despite the common opinion about the variety and unusualness of Indian weapon construction, the weapon of the North Indian region typologically corresponded with the Persian weapon in their main features. Hence

Rev. Artes Marciales Asiát., 10(1), 42-67 2015 
some researchers tend to describe these weapons as Indo-Persian (see Rawson, 1967, pp. 30-33, \& 59).

\section{Persian swordsmanship}

There are numerous Persian manuscripts, poems and stories that describe, specifically and in detail, the different techniques used in Persian swordsmanship such as the 10th-century Šăhnāme [Book of Kings], the 14th-century Majma' al-Ansāb [Complete Collection of Peoples], and Dāstān-e Hosseyn Kord-e Šabestari [The Story of Hosseyn Kord-e Šabestari; ca. 1600 C.E.]. Some of these swordsmanship techniques are represented via the miniatures that are reproduced herein. Although no school of medieval or early modern Persian swordsmanship has survived the passage of time, the traditional stick fighting and stick dancing that is practiced in different parts of Iran reveals techniques that presumably derive from sword and spear techniques of the past. In the province of Sistān, in southeastern Iran, a traditional dance called raqs-e šamšir (sword dance) includes many defensive and offensive techniques. During this dance, both dancers use two steel swords, and as they demonstrate different types of attacks and defensive techniques, they gradually intensify the speed and the executed power of their techniques during the course of the dance. Swordsmanship techniques were also practiced in the zurxāne (house of strength) in varzeš-e pahlavāni (champion's sport; the traditional martial art of Iran) alongside wrestling and associated exercises until the late 1920s or early 1930s. After this period, possibly due to a ban on weapons, training in traditional swordsmanship ceased to be practiced. Nevertheless, varzeš-e pahlavāni offers a comprehensive, all-round martial-system, as it included training exercises for fighting with swords, bows, maces and shields (Luijendijk, 2006, pp. 6-7).

Many literary accounts mention swordsmanship. Examples include Ketāb-e Samak 'Ayyār [Book of Samak Ayyār] (ca. 1100 C.E.), Mobārak Šāh's Ādāb al-Harb va al-Šojā-e [The Customs of War and Bravery] (ca. 1229 C.E.), Mostofi's Zafarnāme [Book of Victories] (ca. 1334 C.E.), and Dastan-e Hosseyn Kord-e Šabestari [The Story of Hosseyn Kord-e Šabestari] (ca. 1600 C.E.). Collectively, these accounts describe methods of carrying, drawing, and sheathing the sword and shield. In addition, they classify sword strikes by the angle of attack. For instance, there are vertical downward attacks. These target the top of the head, both shoulders, both arms, both wrists and the lance shaft. There are vertical upward attacks. These target the armpits, genitals, and lance shaft. There are horizontal strikes. These attack the neck, face, and mouth, the back and the sides of the body, and the legs, shins and knees. There are diagonal attacks. These attack the back of the neck and the abdomen. Although there are accounts of thrusting with swords, thrusting was generally reserved for lances and spears. The manuscripts also describe how to strike using the unsharpened back of swords. Targets included the helmet, which would distract an opponent, and the side of the neck. The target on the neck was the vagus nerve and carotid arteries, where a good blow would cause the person being struck to lose consciousness. To avoid unnecessary damage to swords, edge-to-edge parrying was discouraged. Instead, the back of the sword was used to deflect and parry. In Persian swordsmanship, the shield was used both defensively and offensively. Defensive uses included blocking vertical sword strikes against the head and shoulders and horizontal strikes to the body, while offensive uses included striking with the shield buckles or intentionally striking the shield against the opponent's sword edge (for a more detailed analysis on Persian swordsmanship see Khorasani, 2009a).

The Safavid period manuscript Ālam Ārāye Šāh Tahmāsp [World Ornamentation of King Tahmāsp], written by an unknown author, provides interesting information regarding the challenge matches between Iranian warriors and their enemies. It also gives interesting information about the weapons as well such as maces, sabers, muskets, lassos, daggers and spears. One technique reported in this book is grabbing the sword hand of the opponent. It is reported that Šāhveyrdi Soltān grabbed the sword hand of Daluqeymas, holding his own sword below his thigh and the saddle of his horse. Then, Šāhveyrdi grabbed the chain of the belt and the garibān [standard] of the mail worn by Daluqeymas with his other hand, raised him above his head, and threw him down, thrusting him in the back with his sword before Daluqeymas hit the ground (Ālam Ārāye Šāh Tahmāsp, 1991, p. 91); for a detailed analysis of Persian wrestling techniques used on the battlefield see Khorasani, 2010b, and for the use of daggers see Khorasani, 2009b). 
The Safavid-period story of Hosseyn Kord Šabestari that was written about sword matches (challenge matches) between pahlavānān [champions] during the era of Šāh Abbās Safavid reveals some remarkable techniques of swordsmanship. Hosseyn Kord Šabestari, the hero of the story, is a young pahlavān who wants to gain fame and, therefore, challenges as many pahlavānān as possible to sword-fighting matches. He even travels as far as India for these challenge matches. The remarkable aspect of this story is that not only does it give a detailed account of the terms and terminology regarding different arms and armor used during these matches but also provides some descriptions about various techniques that were used at the time. In the majority of cases, šamšir [sword/saber] were used in combination with separ [shield], meaning that shields were used to fend off and defend against the attacks of the enemy and swords were used to attack the opponent. The sword challenge matches commenced by hitting the shields against each other. At times, the fight commenced by hitting the back/spine of the blades against each other (Dāstān-e Hosseyn Korde Šabestari, 2003, pp. 63 \& 82). Vertical sword blows seemed to be very common as recorded by miniatures depicting many warriors executing this technique (Bahari, 1996, pp. 123 \& 128). A defensive technique against this sword blow was raising the separ [shield] above the head (Dāstāne Hosseyn Kord-e Šabestari, 2003, p. 39). Failure to protect the head against this sword blow led to devastating results since, at times, warriors were cut through to their head, as deeply as four fingers length and sometimes even as deep as their liver (Dāstān-e Hosseyn Kord-e Šabestari, 2003, pp. 66 \& 88). Another sword technique was delivering a blow below the armpit in an upwardcutting motion so that, at times, the sword/saber cut through the arm and came out of the shoulder (Dāstān-e Hosseyn Kord-e Šabestari, 2003, pp. 70-71). At close quarters, the sword hand of the opponent was also grabbed. This technique was applied by grabbing the wrist of the sword arm, disarming the opponent or holding the sword hand of the opponent, and hitting him with the sword (Dāstān-e Hosseyn Kord-e Šabestari, 2003, pp. 63 \& 70). Using feints, such as talking to opponents during sword matches, seems to have been a common technique (Khorasani, 2006, p. 354).

The French traveler Chardin reports on sword handling exercises during the Safavid period. In this respect, Chardin (1988, p. 199) states that this art demanded having a strong and pliant wrist. The Iranian sword masters taught the young trainees to handle the saber with two weights in their hands, turning them up and down, in front and behind, quickly and forcefully (obviously, two swords were used in this exercise). Chardin also points out that in order to make their joints more pliable and the nerves suppler during this exercise, they put two other weights on their shoulders. These weights are made like a horseshoe so that they do not hinder their motion. Chardin also reports that fencing was another exercise practiced during the Safavid era. Fencing was also carried out in public. The fencers laid their arms on the ground at their feet. He further states that these arms consisted of a straight saber and a buckler (Chardin, 1988, p. 199). Before the start, they knelt down and kissed their weapons, touching them with their foreheads. Then, they got up again, taking their weapons in hand, and at the sound of the tabor [drum], they danced and skipped about, making a thousand postures and motions with their weapons very dexterously. Next, they began to hit each other with several strokes of their sabers, and they defended each strike with their bucklers. Chardin states that they always struck with the edge, meaning that they used cutting techniques with their sabers. Chardin also states that if they did not position themselves too near each other, they used the point of their sabers. Chardin further states that these fencers took their training seriously and sometimes drew blood, but if the combat became too serious, they were separated (Chardin, 1988, p. 201). Judging by historical chronicles and accounts, it seems that systematic cutting tests were an integral component of the training of a swordsman. This procedure is mentioned in the manuscript Romuz-e Hamze [Secrets of Hamze, collected in the second half of the 15 century] (1940, p. 661) with the expression "to hit a sheep [on the back] with a blade/sword and cut it in two (Falsafi, 1996, vol. 2, p. 453).

Most Persian shields were made of buffalo or rhino hide that were used in warfare as reported in Persian manuscripts (see Yazdi, 1957, p. 362; Širuye Nāmdār, 2005, p. 401; Beyqami, 2002, vol. 2, p. 173; al-Kāteb al-Rajāni, 2004, p. 423; Ferdŏsi, 1995, p. 604; Asadi Tusi, 1938, p. 414; Āsef, 2003, p. 394). Although some pieces were made of steel as well. Persian manuscripts report that one carried a shield on the back with the help of a belt/leather rope that went through a hole made close to the rim of the shield or the shield handles that were placed in the middle of the back of the shield. Another way of carrying a shield was via a baldric that held the shield on the back. 
Persian manuscripts describe different techniques for executing sword strikes on foot or on horseback. Some of these expressions are general and do not specify any targets or sequences of movements of the applied techniques. In the following, some of the most common techniques are described.

\subsection{Downward vertical strikes}

Based on an analysis of Persian manuscripts and miniatures, downward vertical strikes were a very frequent technique. The general concept of this technique was tiq bar sar rändan [to hit the head with a blade/sword] as indicated in the 14th-century manuscript Zafarnāme [Book of Victories] (Yazdi, 1957, p. 177). In the following some of these techniques will be discussed:

a) Attacking the top of the head with a downward vertical strike: The majority of techniques in Persian swordsmanship mentioned in the combat scenes in Persian manuscripts involved attacking the head with a vertical downward strike. In Ancient Iran, Sassanian silver plates show Sassanian kings executing this technique on horseback using their double-edged straight swords cutting down the boars in hunting. The same technique can be used against a man sitting on horseback irrespective of the height of the opponent. One could also find the use of this technique in representations of warriors in miniatures. This technique is also often mentioned when swords had a slight curvature as mentioned in the 11th-century manuscript Samak Ayyār (al-Kāteb alRajāni, 2004, p. 392) as šamšir bar sar va farq zadan [to hit [the opponent on] the top of the head/vertex]; the Safavid-period manuscript Ālam Ārāye Šāh Tahmāsp [The World Ornamentation of King Tahmāsp] (1991, p. 292) refers to this technique as šamšir bar farq zadan [to hit [the opponent] with a sword on the top of the head; to hit someone on the top of his head with a sword], and the Safavid-period manuscript Dāstān-e Hosseyn Kord-e Šabestari [Story of Hosseyn Kord-e Šabestari, written during Šāh Abbās Safavid period] (2003, pp. 124 \& 246) refers to this technique by the expressions šamšir rā havāle-ye farq nemudan [to hit with a sword on the top of the head/vertex] and tiq be farq andāxtan [to hit the forehead with the sword]. Different miniatures from the 14-century manuscript Xāvarānnāme [Book of the East] by Ibn Hesām Xusofi Birjandi show the application of the technique šamšir bar farq zadan [to strike the top of the head with a sword] (see Picture 1).

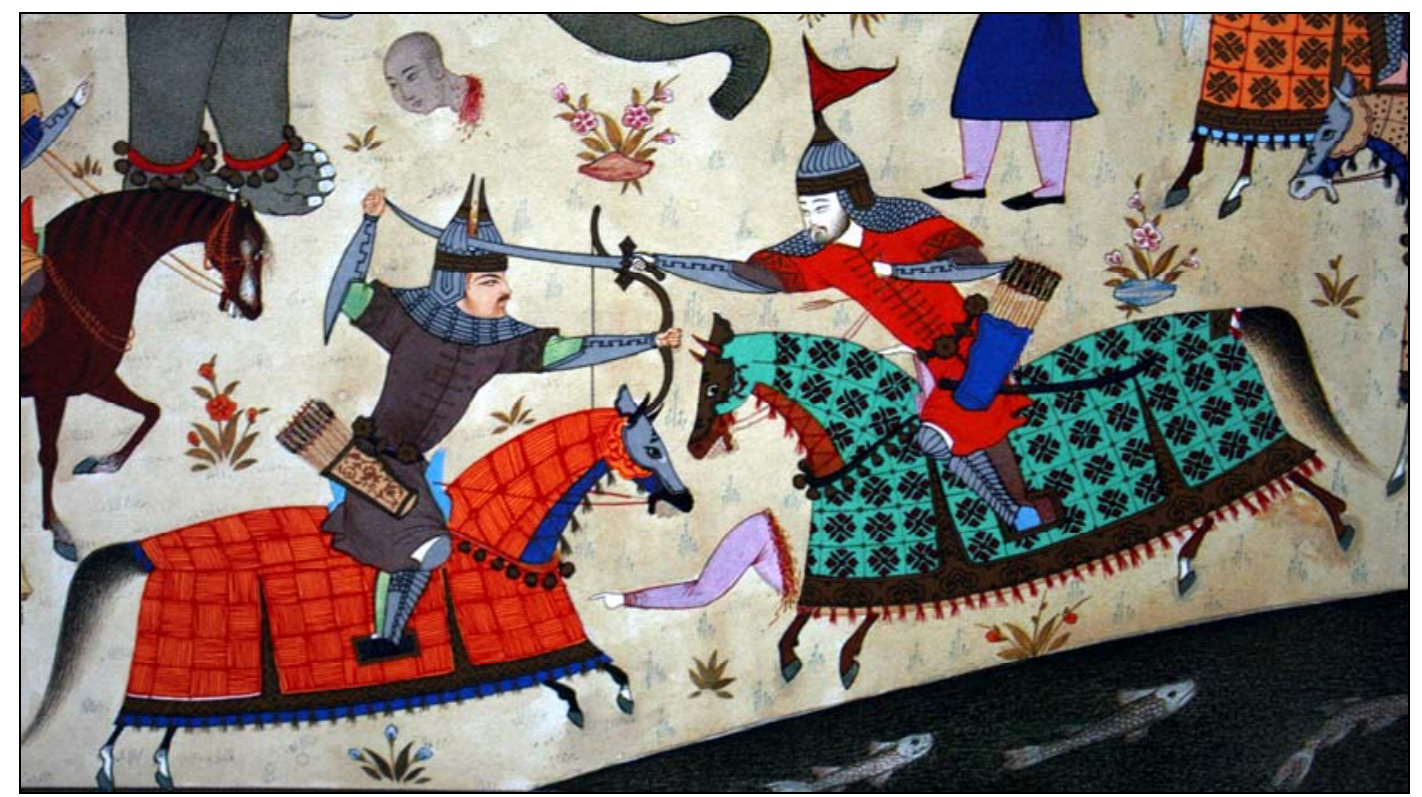

Picture 1. The miniature titled "The second combat between the Indian Princes Gav and Talhand" from the manuscript of the Šăhnāme-ye Bāysonqori shows how a mounted warrior on the right has cut through the helmet of a mounted archer with a vertical downward strike.

b) Attacking the shoulder with a downward vertical strike: The shoulder is another target area for a downward vertical strike. The 14th-century manuscript Zafarnāme [Book of Victories] 
describes this technique as tiq bar sar-e ketf zadan [to hit the top of the shoulder with the sword] (Mostufi, 1999, p. 317). The Safavid-period manuscript Dāstān-e Hosseyn Kord-e Šabestari [Story of Hosseyn Kord-e Šabestari, written during Šāh Abbās Safavid period] describes this technique as šamšir bar ketf zadan [to hit the shoulder with a sword [in a downward movement]] (see Dāstān-e Hosseyn Kord-e Šabestari, 2003, p. 88). The Safavid-period manuscript Dāstān-e Hosseyn Kord-e Šabestari [The Story of Hosseyn Kord-e Šabestari] reports that this technique was so effective that the sword blade could cut through the shoulder and come out from the armpit: Bahrām tiq rā bar ketf Sohrāb Beyk zad ke az zir baqalaš bedar raft [Bahrām hit the shoulder of Sohrāb Beyk with a sword [so hard] that it came out from his armpit] (Dāstān-e Hosseyn Kord-e Šabestari, 2003, p. 215). The manuscript Širuye Nāmdār [The Famed Širu] (2005, p. 244) also talks about this technique: bar ketf zadan va barq-e tiq az zir-e baqal nemudār gaštan [to strike the shoulder and to reveal the glitter of the blade below the armpit; to strike the shoulder so that the blade cuts through it and appear below the armpit] (see Picture 2).

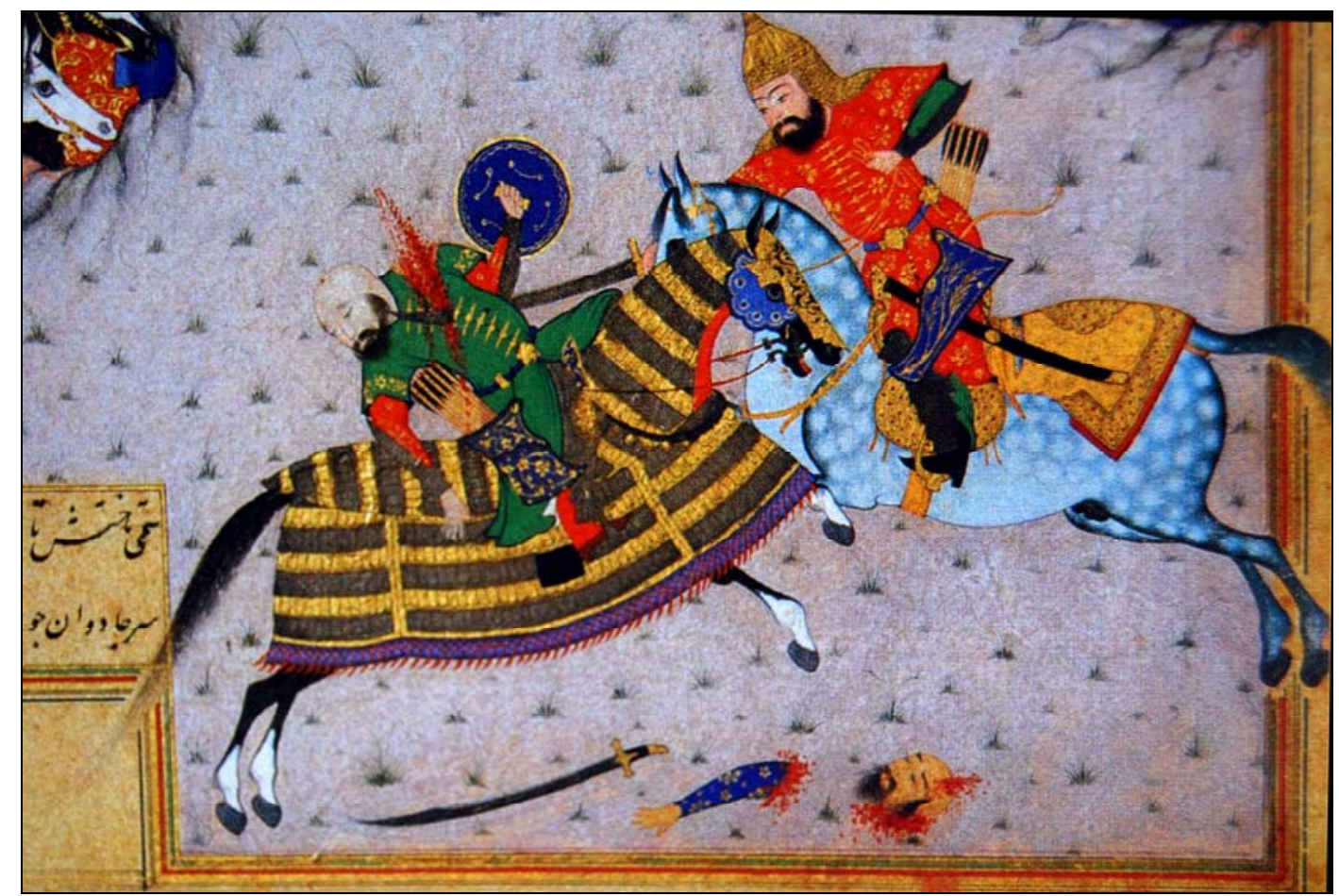

Picture 2. In a miniature from the manuscript of the Šăhnāme-ye Šāh Esmä'ili one sees a combat scene between two mounted warriors. Note how the warrior on the right has cut off the shoulder of the warrior on the left by applying the technique šamšir bar ketf zadan (Courtesy of Rezā Abbāsi Museum).

c) Attacking the arm with a downward vertical strike: Another target for a vertical downward strike was the arm or more specifically forearm. The manuscript Abu Moslemnāme [Book of Abu Mpslem] reports on the application of this technique as šamšir bar dast zadan [to strike the hand with the sword] (Tartusi, 2001, vol. 3, p. 427) (see Picture 3).

d) Attacking the wrist with a downward vertical strike: Another target for a downward vertical sword strike was the wrist of the opponent as described in the manuscript Ālam Āräye Tahmāsp Tahmāsp [World Ornamentation of King Tahmāsp] (1991, p. 292) with the description šamšir bar band-e dast zadan [to hit [the opponent's] wrist [holding his sword] with a sword].

\subsection{Upward vertical strikes}

These strikes are done upwards in a vertical motion as will be shown below:

a) Attacking the armpit via an upward strike: A sword strike below the armpit via an upward strike was a frequent technique of this type as mentioned in different Persian manuscripts. The manuscript Abu Moslemnāme [Book of Abu Moslem] explains that this technique was used when the 
opponent tried to execute a downward vertical strike on the head (Tartusi, 1991, vol. 3, p. 273). That is to say this technique was used as a counterattack. The manuscript Romuz-e Hamze [Secrets of Hamze collected in the second half of the 15 century] (1940, pp. 87 \& 96), collected in the 15th century, describes that when executed with force, this technique resulted in having the sword blade get out of the shoulder area. The Safavid-period manuscript Ālam Ārāye Šāh Tahmāsp [World Ornamentation of King Tahmāsp] (1991, p. 330) also reports about this technique with the expression tiq dar zir-e baqal navāxtan [to hit [the opponent] with a sword under his armpit]. Another Safavid-period manuscript Dāstān-e Hosseyn Kord-e Šabestari [Story of Hosseyn Kord-e Šabestari written during Šāh Abbās Safavid period] (2003, pp. 88 \& 189) describes that this technique in different ways; either it could be used as a counterattack when the opponent raised his arm for delivering a downward vertical sword strike or when one used a feinting technique with a downward vertical strike and the opponent raised his shield to protect his head, one could execute an upward vertical strike under the armpit of his shield hand. In those cases one delivered a sword strike below the armpit of either the hand holding a sword or the hand holding the shield. The Safavid-period manuscript Dāstān-e Hosseyn Kord-e Šabestari [Story of Hosseyn Kord-e Šabestari written during Šāh Abbās Safavid period] (2003, p. 189) reports about this technique: čenān tiq rā bezir-e baqal Hosseyn Bahādor zad ke barq-e tiq az bālāye farqaš bedar raft "[He] hit Hosseyn Bahādor [so hard] under the armpit that the glitter of the sword came out of the top of his head". In another part of the same manuscript, one refers to the same technique: tiq rā čenān bezir-e baqalaš zad ke barq-e tiq az ketfaš zabāne kešid "He hit him [so hard] under the armpit with the sword that the glitter of the sword came out of his shoulder" (Dāstān-e Hosseyn Kord-e Šabestari, 2003, p. 283).

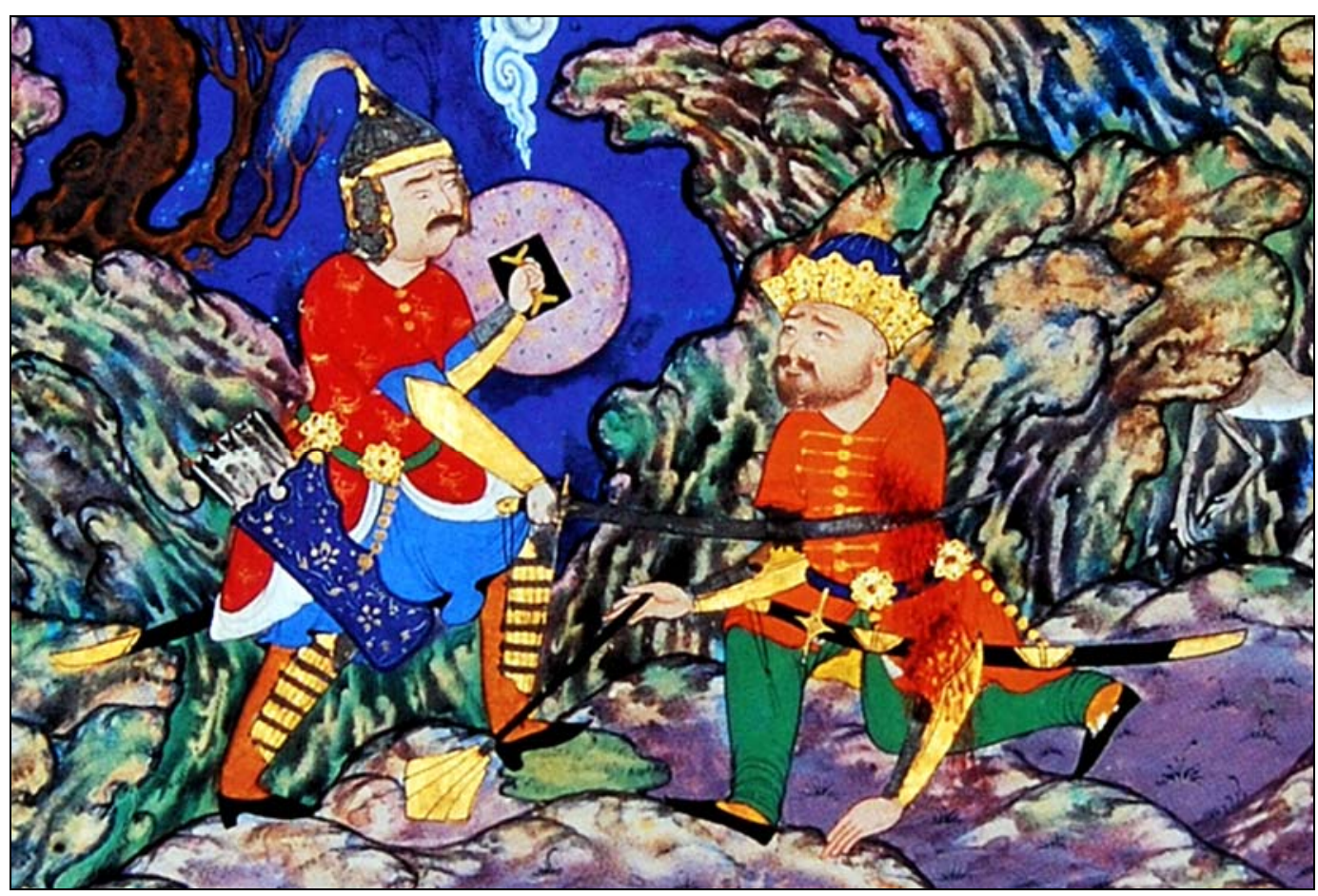

Picture 3. A miniature from the Safavid-period manuscript Šāhnāme-ye Šāh Tahmāspi [Book of Kings of Tahmāsp] titled "Rahām is cutting off the arm of the magician" attributed to Qāsem Ali shows the application of the technique šamšir bar dast zadan. Note how Rahām has cut off the arm of the magician with a downward vertical strike of his sword (Courtesy of Muze-ye Honarhā-ye Moāser Irān).

b) Kneeling down and attacking the armpit with an upward strike: A variation of this technique involves kneeling down and attacking the armpit of the opponent with an upward vertical strike as reported in the Safavid period manuscript Dāstān Hosseyn Kord-e Šabestari (2003, p. 70): bar zānu nešastan va tiq andāxtan [to kneel down and to throw [strike with] the sword; this technique included kneeling down on one leg and hitting the opponent under the armpit].

c) Attacking the groin with an upward vertical strike: Another target area for an upward vertical strike was the groin as indicated in the manuscript Xāvarānnāme [Book of the East] from 
the 15th century: tiq bar tohigāh zadan [to hit the groin with a blade/sword] (Xusofi Birjandi, 2002, p. 88).

\subsection{Horizontal strikes}

Horizontal strikes include a number of different strikes that were executed from the right to the left or from the left to the right in a horizontal angle. There are different target areas for this type of strikes, such as the neck, the sides of the body and the legs. Some of these techniques are described in detail in Persian manuscripts as will be shown below:

a) Attacking the neck with a horizontal strike: A certain specific horizontal strike that could be used was a horizontal sword strike on the neck from left to right or right to left. The 14thcentury manuscript Zafarnāme [Book of Victories] explains that technique as tiq bar kardan zadan [to hit the neck with a blade/sword] (Mostufi, 1999, p. 696). The manuscript Romuz-e Hamze [Secrets of Hamze collected in the second half of the 15 century] (1940, p. 272) also describes this technique as šamšir bar gardan navāxtān [to strike someone [the opponent] with a sword on the neck]. The Safavid-period manuscript Ālam Ārāye Šāh Tahmāsp [World Ornamentation of King Tahmāsp written during the Safavid period] (1991, p. 293) mentions this technique as šamšir bar gardan zadan [to hit someone [the opponent] with a sword on the neck]. The manuscript Dārābnāme [Book of Dārāb] (Beyqami, 2002, vol. 2, p. 577), which is based on ancient Iranian tales, explains the efficiency of this technique when it was executed with much force: tiq bar gardan zadan va sar dar xāk andāxtan [to hit the neck with a blade/sword and to cast it off to the ground] (see Picture 4).

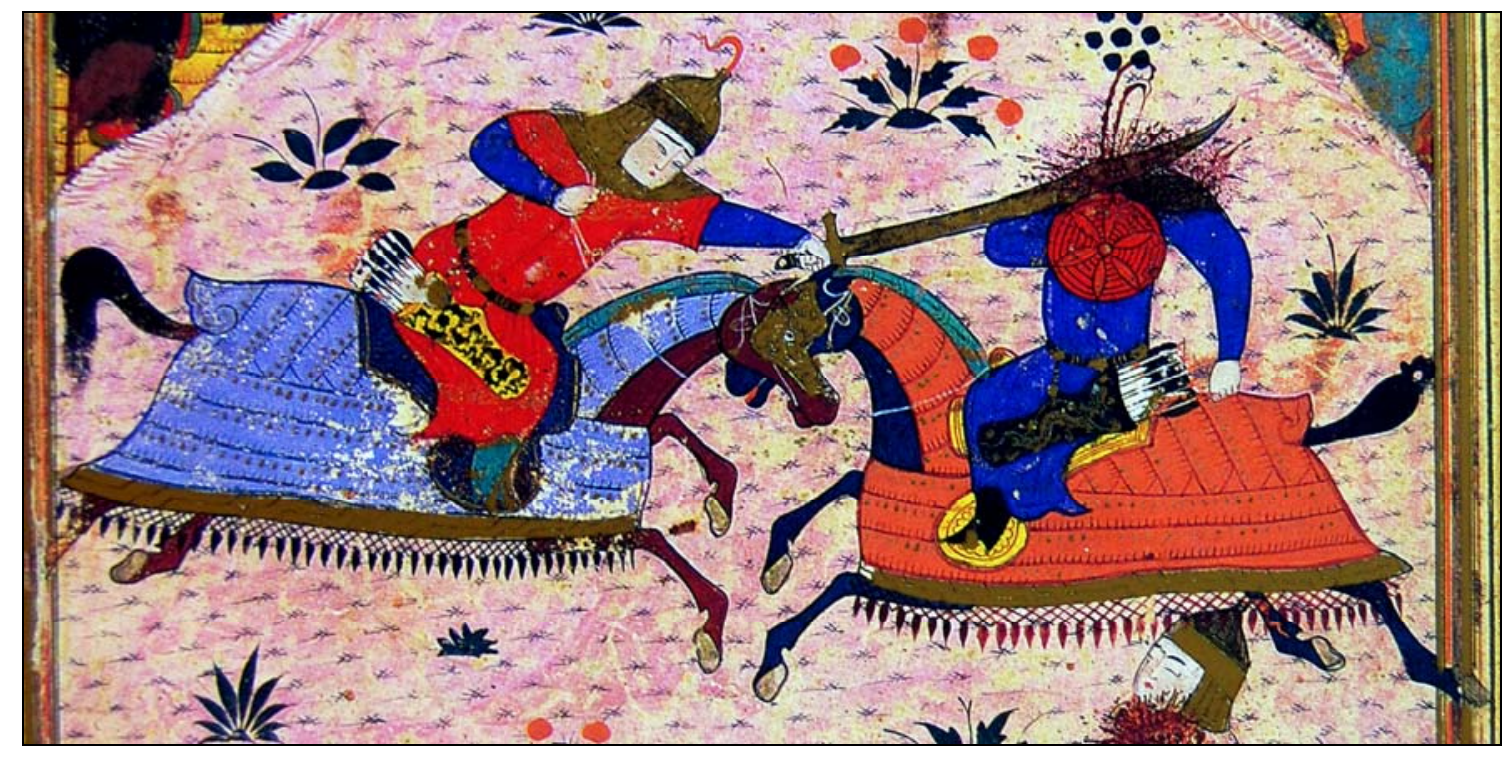

Picture 4. The miniature titled "Qobād encounters his foe" shows how a mounted Qobād is applying the technique šamšir bar gardan zadan [to hit the back with a blade/sword] to cut off the head of his enemy (Xusofi Birjandi, 2002, p. 123).

b) Attacking the back with a horizontal sword strike: Another target area for a horizontal or vertical strike was the back. One could execute this technique in different situations, for example when the opponent raises his shield to place it in front of his face or above his head to protect these areas. The manuscript Eskandarnāme [Book of Eskandar] (Hakim, unspecified date, p. 554) from the 12th century describes this technique as šamšir be kamar zadan [to hit [the opponent on] the back with the sword]. The 14th-century manuscript Zafarnāme [Book of Victories] (Mostufi, 1999, p. 109) explains this technique as tiq bar kamargāh zadan [to hit the back with a blade/sword]. For other expressions see tiq bar kamar zadan [to strike the back with a blade/sword] in the manuscript Romuz-e Hamze [Secrets of Hamze collected in the second half of the 15 century] (1940, p. 36); šamšir bar kamar zadan [to hit the back with a blade/sword] in the Safavid-period manuscript Ālam Ārāye Šāh Tahmāsp Tahmāsp [World Ornamentation of King Tahmāsp] (1991, p. 293); and tiq bar 
kamar navāxtan [to hit the back with a blade/sword] in the manuscript Širuye Nāmdār [The Famed Širu] (2005, p. 109) (see Picture 5).

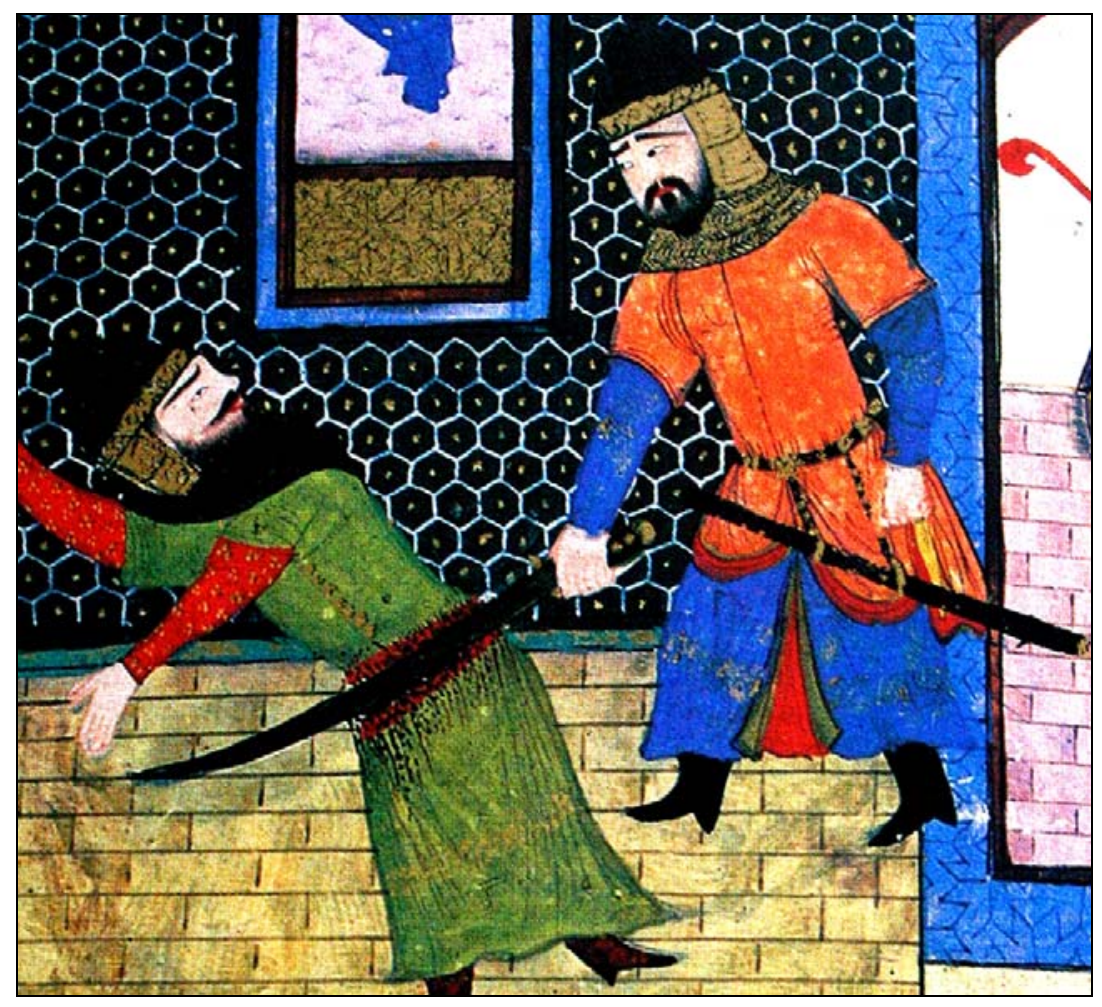

Picture 5. A miniature titled "Qibt is slain by Abu al-Mihjan" taken from the 14th-century manuscript Xāvarānnāme by Ibn Hesām Xusofi Birjandi shows how Emām Ali kills Qibt by applying the technique of šamšir bar kamar zadan (Xusofi Birjandi, 2002, p. 46).

c) Attacking the middle/sides of the body with a horizontal strike: Another horizontal sword strike consisted in attacking the middle/side of the body. The manuscript Majma' al-Ansāb [Complete Collection of Peoples] written in 733 Hegira (1333 C.E.) describes this technique as šamšir bar pahlu zadan [to strike the side/middle of the body with a sword] (Šabānkāre'i, 2002, p. 338). The 14th-century manuscript Jäme al-Tavārix [The Complete Histories] describes the application of this technique as miyān rā be do nim zadan [to cut someone from the middle into two parts (by using a šamšir)] (Rašidoldin Fazlollāh Hamedāni, 1985, p. 752). The manuscript Romuz-e Hamze [Secrets of Hamze collected in the second half of the 15 century] (1940, pp. 94 \& 255) describes this technique tiq bar davāl-e kamar navāxtan [to hit the back with a blade/sword] adding that a powerful use of this technique could cut off the body until the navel: tiq rā bar davāl kamar zadan va tā nāf šekāftan [to hit the back on the belt and cut to the navel]. The manuscript Dārābnāme [Book of Dārāb] informs that a powerful horizontal strike of this type could cut off the body in two parts: tiq bar miyān zadan va čon xiyār be do nim kardan [to strike the middle of the body with a sword and to cut it like a cucumber] (Beyqami, 2002, vol. 2, p. 577).

d) Attacking the belly with a horizontal strike: The belly was another target for a horizontal sword strike as attested by a number of Persian miniatures such as a) a miniature titled "Emām Ali trounces Ardešir" taken from the 14-century manuscript Xāvarānnāme [Book of the East] by Ibn Hesām Xusofi Birjandi which shows how Emām Ali has cut off Ardešir by applying this technique (Xusofi Birjandi, 2002, p. 100), b) a miniature titled "The youth is unfettered by Emām Ali" taken from the same manuscript which shows how Emām Ali is attacking his opponent by applying the same technique (Xusofi Birjandi, 2002, p. 132) and c) a miniature from the Timurid-period manuscript Šāhnāme-ye Bāysonqori [Book of Kings of Bāysonqori] which shows how a mounted warrior on the left has cut off his opponent by executing this technique (see a copy of this manuscript which is written by Ja'far Tabrizi Bāysonqori from Golestān Palace Museum). The strike could be executed from left to right or from right to left depending on the position of the opponent's body. 
e) Attacking the face with a horizontal strike: Another area for horizontal strikes was the face as explained in the manuscript Romuz-e Hamze [Secrets of Hamze collected in the second half of the 15 century] $(1940$, p. 44) with the expression šamširbar surat zadan [to strike the face with a sword].

\subsection{Diagonal sword strikes}

Some sword strikes were a combination of horizontal and vertical sword strikes when one takes the angle of attack into consideration.

a) Attacking the leg, the shin or the knee with a diagonal strike: Another target for a diagonal sword strike were the legs. The manuscript Romuz-e Hamze [Secrest of Hamze collected in the second half of the 15 century] (1940, p. 530) talks about this technique as šamšir bar pāy zadan [to hit the leg with the sword]. A strong strike of this type could cut the leg as described by the 14thcentury manuscript Zafarnāme [Book of Victories] (Mostufi, 1999, p. 85). The shins were used as another target area for diagonal sword strikes. Similar to the previous strike, one executes this technique diagonally on foot. The 14th-century manuscript Zafarnāme [Book of Victories] describes this technique as tiq bar sāq zadan [to hit the shin with a blade/sword] (Mostufi, 1999, p. 87). Another target area for a diagonal sword strike was the knee.

b) Attacking the back of the neck with a diagonal sword strike: On horseback, this technique could be applied in a horizontal or diagonal angle. On foot, one could execute this technique diagonally as described the 10th-century manuscript Abu Moslemnāme [Book of Abu Moslem] with the expression tiq bar pas-e sar zadan [to strike the back of the head [of the opponent] with a blade/sword] (Tartusi, 2001, vol. 3, p. 427).

c) Striking the side of the body with a diagonal strike: With this technique one attacked the side of the opponent's body with a diagonal strike. The manuscript Romuz-e Hamze [Secrest of Hamze collected in the second half of the 15 century] (1940, p. 188) reports that a powerful strike of this type could cut off the body until the armpit as the expression šamšir bar kamar zadan va az zir-e baqal dar ämadan [to hit [the opponent on] the back with the sword so that the sword comes out of the armpit].

\subsection{Thrusting with the tip of the sword}

Persian manuscripts rarely report about thrusting with the tip of the sword. This was due to the fact that Persian warriors used their lances, daggers and knives for thrusting purposes. In spite of this, there are expressions that describe the use of the tip of the sword to thrust such as nok-e šamšir rā havāle kardan [to hit with the tip of a sword/ to thrust with the tip of a sword] in the 18th-century manuscript Tārix-e Ahmad Šăhi [History of Ahmad Šāhi] (al-Jāmi, 2001, p. 13) and foru kardan [to thrust with a sword], during the Qājār period (see Modarresi, et al., 1991, p. 426).

\subsection{Striking with the back of the sword}

Some Persian manuscripts and Persian literature in general report that one used the back of the sword blade for striking. Some of these techniques are presented as follows.

a) Striking the opponent's helmet with the back of the sword's blade: In this technique, one used the back of the sword's blade to strike the opponent's helmet to distract him. After this strike, one continued with other strikes for cutting down the opponent. This strike is mentioned in the 15th-century manuscript Dārābnāme [Book of Dārāb] with the expression pošt-e šamšir bar kolāhxud zadan [to strike the helmet with the back of the sword] (Beyqami, 2002, vol. 2, p. 179).

b) Striking the back of the sword against the back of the opponent's sword: Persian warriors used their shields to defend themselves. Sometimes they also used their armguards to protect themselves or avoided the strikes by sidestepping or stepping backward. However, there are also accounts about the use of the back of the sword for defending oneself against the opponent's sword 
strikes for deflecting or parrying purposes. The Safavid-period manuscript Dāstān-e Hosseyn Kord-e Šabestari [The Story of Hosseyn Kord-e Šabestari] (2003, p. 82) talks about the use of this technique: pošthāy-e šamširrā yekdigar āšnā kardan [lit. to acquaint the back of the swords with each other; to hit the back of the swords against each other].

\subsection{Feinting techniques}

Feinting techniques were frequently used in Persian swordsmanship. First, one feinted a certain strike, and when the opponent raised his shield to defend himself, one changed the trajectory of the technique and executed another strike.

a) Feinting a downward vertical strike and executing a horizontal or vertical upward strike: Feinting a downward vertical strike towards the head, followed by a horizontal strike to the upper body was a common technique as described by Persian manuscripts. By feinting a vertical strike, the opponent raises his shield to protect his head. In this situation, one changes the direction of the technique and executes a strike to the upper body, the back or the sides of the body. A counterattack could also be an upward vertical strike to the armpit. The manuscript Samak Ayyār from the 11th-century describes this technique as šamširrā gardāndan [to turn the sword] (alKāteb al-Rajāni, 2004, p. 422). The following phrases from the 11th-century manuscript Samak Ayyār show how this technique was used:

He brought down his sword to hit Simāb [on his head], but Simab brought his shield over his head. Šāhān, with an extreme dexterity, turned his sword and hit Simāb on his waist with such a force that the sharpness [of the edge] of the sword cut him in two like a cucumber. (al-Kāteb alRajāni, 2004, p. 1263)

After turning the sword, this technique can also be applied to cut the armpit in an upward motion:

And suddenly he attacked and brought down his sword to hit the head of Ād. Thus, Ād brought his shield above his head and Qamqām turned [the direction] of his sword and hit Ādbelow his armpit and cut off his arm and head. (al-Kāteb al-Rajāni, 2004, p. 1263)

The Safavid-period manuscript Ālam Ārāye Šāh Tahmāsp Tahmāsp [World Ornamentation of King Tahmāsp written during the Safavid period] (1991, p. 33) also describes this technique with the expression: dast va tiq rā xābāndan [lit. to bring down the hand and the sword; a technique in swordsmanship where first an attack to the head is feinted and then the pelvis/hips are attacked by the sword].

b) Attacking with a vertical sword strike and changing the hands: The manuscript Romuz-e Hamze [Secrets of Hamze collected in the second half of the 15 century] (1940, pp. 87 \& 223) explains that during the combat one feinted a downward vertical sword with the sword in the right hand and when the opponent raised his shield to protect his head from the left side, one changed the hand holding the sword from the right to the left and hit the opponent on the right side on the shoulder with a downward vertical strike. This technique is called šamširrā be dast čap gereftan va forud âvardan [to hold the sword in the left hand and to bring it down [to strike]].

\subsection{Combinations}

The combinations included executing a number of techniques for surprising and dominating the opponent and reducing the opportunities he has to defend himself.

a) Using the number eight: A combination in sword technique was moving the sword in four directions drawing a figure similar to the number eight with it as indicated by the 11th-century mansucript Samak Ayyār with the expression šamšir rā be čahr taraf harkat dādan [lit. to move the sword in four directions]. This was a technique used in Persian swordsmanship, where the sword was moved in front of the body in a figure-of-eight pattern or above the head in a full circle of 360 degrees before hitting the opponent on his head. One executed this technique to gain more 
momentum and power before executing a downward vertical strike on the opponent's head. The following sentence from the 11th-century manuscript Samak Ayyār describes how this technique was applied (al-Kāteb al-Rajāni, 2004, p. 1093): "Then, they moved their swords in four directions and then [used] its strike [force] to hit their heads and scalps/pates."

b) Attacking with a combination of horizontal strikes: This combination consists of attacking with a horizontal strike from the left followed by a horizontal strike from the right. One could also execute this technique the other way around. The manuscript Romuz-e Hamze [Secrets of Hamze collected in the second half of the 15 century] $(1940$, p. 224) talks about this combination as $b \bar{a}$ šamšir az čap va rāst zaxm zadan [to strike with a sword from left and right] and the 14th-century Zafarnāme [Book of Victories] indicates šamšir az čap va rāst zadan [to strike with the sword from left and from right] (Nāderi, 1968, p. 89).

\subsection{Grabbing the hand}

Persian manuscripts report how Persian warriors grabbed the sword hand of their opponent trying to wrestle them down with the aim of making them lose their weapon. At times, after grabbing the sword hand of the opponent, one executed a counterattack with his own weapon.

a) Grabbing the wrist of the opponent's hand that is holding a sword: This technique is mentioned very often. To execute this technique, one streched out the left hand and tried to grab the wrist of the sword hand of the opponent when he was trying to execute a downward vertical strike and tried to grab the wrist of the sword hand of the opponent when he was trying to execute a downward vertical sword strike. The 12th-century manuscript Eskandarnāme [Book of Eskandar] describes this technique with the expression: band-e dast rā gereftan [to take hold of the joint of the hand]. This was a technique where a combatant tried to catch the joint of the hand of the opponent that was holding a sword (Hakim, unspecified date, p. 544). After grabbing the opponent's wrist, one punched him in the head using the other hand. The manuscript Romuz-e Hamze [Secrets of Hamze collected in the second half of the 15 century] (1940, p. 410) describes this technique as band-e dast rā gereftan va mošt bar kalle zadan [to grab the wrist [of the opponent] and punch [him] on the head]. Persian manuscripts also report about the application of different types of this technique. Generally, by applying this technique one grabbed the wrist of the opponent, held him and threw him to the ground. This technique could be executed on horseback or on foot.

b) Grabbing the spear/lance shaft: When the opponent tried to thrust with his lance/spear, one grabbed the lance/spear shaft and executed a counterattack or tried to pull out the lance/spear from the opponent's hands by pulling it out as described in the manuscript Romuz-e Hamze [Secrets of Hamze collected in the second half of the 15 century] (1940, p. 441) with the expression do angošt derāz kardan va galu-ye neyze rā gereftan va be dur andāxtan [to extend two fingers and to get hold of the spear socket [of the opponent] and to throw it away].

\subsection{Deflecting techniques}

Deflecting techniques include a number of techniques that include avoiding the opponent's attacks by taking a side step, a step backward, twisting the body or pulling back the hand/arm.

a) Pulling back the hand/arm: Pulling back the hand/arm was used when the opponent tried to grab the hand holding the sword; in this technique the swordsman who was about in the middle of striking pulled his arm back towards himself, hence, shortening the range so that he could hit the arm/hand of the opponent that was trying to grab the wrist of the swordsman as described in the 12th-century manuscript Eskandarnāme [Book of Eskandar] in the expression dast ra kutāh kardan [lit. to shorten the hand] (Hakim, unspecified date, p. 544).

b) Turning the upper body and attacking with a downward vertical sword strike: With stepping backwards and turning the upper body, one avoided the opponent's attack and from this position, one executed a downward vertical strike. One could execute this technique on foot or on horseback twisting the body. The 14th-century manuscript Zafarnāme [Book of Victories] describes this technique as az bālā-ye zin-e xod pičidan va šamšir hamāyelvār forud āvardan [to turn about in 
one's own saddle and bring down the sword in a direction as indicated by the [angle of] sword belt] (Yazdi, 1957, p. 118).

c) Deflecting the opponent's sword with the sword: With this technique one used his sword to deflect a sword strike of the opponent as described in the 15th-century manuscript Dāräbnāme [Book of Dārāb] with the expression šamširrad kardan [to deflect the sword [strike]] (Beyqami, 2002, vol. 1, p. 296).

d) Using the back of the sword blade for deflecting and parrying: The use of the back of the sword blade for deflecting and parrying was a technique that Persian manuscripts refer to such as in the expression pošt-e tiq bar dam-e tiq dãdan [lit. to give the back of the blade to the edge of the [coming] blade; to defend with the back of the sword against the incoming sword edge of the opponent] in the manuscript Ālam Ārāye Šāh Tahmāsp [World Ornamentation of King Tahmāsp written during the Safavid period] (1991, p. 33):

\begin{abstract}
Xān attacked that big army with thousand men and in the middle of the fray, he intercepted the way of Nāser Pāšāand Nāser Pāšã attacked him with a sword. Xān defended his sword with the back of [his own] sword so that the tip of [the opponent's] sword hit [his own] handguard and the sword [of the opponent] broke: He [Xān] threatened him [with his sword], and he [Nāser Pāšā] brought up his shield to protect his head and Xān brought down his hand and sword and on his belt and cut him in two like an old plane tree.
\end{abstract}

e) Using the sword for parrying: Persian manuscripts do not generally mention the use of the sword as a parrying instrument against the incoming strikes executed by the opponent because as it was mentioned before, warriors chiefly used their shield for defending themselves. However, the technique of parrying with the sword is mentioned in the 11th-century manuscript Samak Ayyār as šamšir dar moqābel gereftan [lit. to hold the sword against] (al-Kāteb al-Rajāni, 2004, p. 884): "Kāveh wanted to strike his sword at Farroxruz, but Farroxruz held his sword against it. Kāveh was holding the edge of his sword against him and [therefore] his sword broke in two."

Other variation of this technique that was not very common consists in parrying with the sword edge as explained in the manuscript Romuz-e Hamze [Secrets of Hamze collected in the second half of the 15 century] (1940, p. 543) in the expression šamšir bar dam-e šamšir zadan [to strike the edge of the sword against the edge of another sword]. The results of this technique, which was used as the last resort, were the fracture of the blade as described in the 11th-century manuscript Samak Ayyār with the expression šamšir šekastan [to break the sword] (al-Kāteb alRajāni, 2004, p. 552). Persian manuscripts report on these fractures: "And they hit each other with four sword strikes until their swords broke" (al-Kāteb al-Rajāni, 2004, p. 552). The 15th-century manuscript Dārābnāme [Book of Dārāb] reports that the results of this technique were that the edges ended up looking like a saw or serrated: šamšir arre šodan [lit. to have the [blade of] sword look like a saw/serrated; it refers to the nicks on the edge of the blade suffered during the combat] (Beyqami, 2002, vol. 1, p. 278). The 11th-century manuscript Samak Ayyār also reports about the edges of swords that ended up being serrated on the battlefield: čon arre dandāne dandāne šodan [to become serrated like a saw; referring to the edges of swords during combat that take nicks and dents on the edges] (al-Kāteb al-Rajāni, 2004, p. 425). The 12th-century manuscript Eskandarnāme [Book of Eskandar] talks about the end result of this technique when the edges of swords broke: damhä-ye šamšir foru rixtan [lit. to tear down the sword edges; to break the sword edge completely] and az šamšir faqat qabze māndan [to leave only the handle of a sword; referring to the damage taken by a sword during combat where the blade breaks and only the handle remains in the hand] (Hakim, unspecified date, p. 573).

\title{
3.11. Using the shield for attack and defence
}

The main instrument for parrying the sword strikes was a shield that had been used in Ancient Iran and continued to be used up in the Qājār period (1794-1925 C.E.). Persian manuscripts often describe the use of shields for parrying the sword strikes. Taking up the shield for defending oneself is separ gereftan [to take shields; to resist] (Digital Lexicon of Dehxodā, 2006). 
a) Striking with shield buckles: Shields were not only used for defense purposes but they were also actively used for attacking or for creating distance from an opponent. Some examples of striking the shield against the shield of the opponent can be observed in the 15th-century manuscript Dārābnāme [Book of Dārāb] with the expression qobbe-ye separ bar qobbe-yesepar zadan [to hit the shield buckles/shield against the shield buckles/shield of the opponent] (Beyqami, 2002, vol. 2, p. 591), or in the manuscript Dāstān-e Hosseyn Kord-e Šabestari [The Story of Hosseyn Kord-e Šabestari written during Šāh Abbās Safavid period] (2003, pp. 66 \& 88) with the expressions qobbe-yesepar be sar yekdigar āšna kardan [lit. to acquaint the shield buckles with each other's heads; to hit the shield buckles/shield against the shield of the opponent] and qoppe separ bar yekdigar āšnā nemudan [to place the shield buckles on/above the head].

b) Striking the shield against the opponent's sword edge: Warriors used their shield to actively strike against the sword edge of their opponent before it could get enough momentum. The technique to strike actively against the sword edge of their opponent, before it could gain enough momentum to strike with, is described in the manuscript Širuye Nāmdār [The Famed Širu] (2005, p. 178) with the expression separ bar dam-e tiq dädan [to put/strike the shield against the sword edge [of the opponent]]. A variation of this technique involved twisting/turning the shield and striking it against the sword edge as described by the manuscript Romuz-e Hamze [Secrets of Hamze collected in the second half of the 15 century] (1940, p. 317) with the expression qobbe-ye separ rā be gardeš dar-āvardan va be dam-e šamširzadan [to turn the shield buckles and strike against the sword edge].

c) Defending against the downward vertical sword strikes against the head: Placing the shield above the head for defending it against incoming downward vertical strike is a frequent technique mentioned and shown in Persian manuscripts. This technique is explained with the expression separ bar sar âvardan [lit. to bring the shield above the head; to protect the top of the head with the shield] in the 10th-century Šăhnāme [Book of Kings] (Ferdŏsi, 1995, p. 1347), separ bar sar kešidan [lit. to pull the shield above the head; to protect the top of the head with the shield] in the 12thcentury Eskandarnāme [Book of Eskandar] (Hakim, unspecified date, p. 288; also see Rašidoldin Fazlollāh Hamedāni, 1985, p. 727; Romuz-e Hamze [Secrets of Hamze collected in the second half of the 15 century], 1940, p. 317 and Dāstān-e Hosseyn Kord-e Šabestari [Story of Hosseyn Kord-e Šabestari written during Šāh Abbās Safavid period] (2003, p. 39). The 14th-century manuscript Zafarnāme (Yazdi, 1957, p. 104) presents this technique with the expression separ dar sar kešidan [to pull the shield above the head]. The manuscript Dāstān-e Hosseyn Kord-e Šabestari [The Story of Hosseyn Kord-e Šabestari written during Šāh Abbās Safavid period] (2003, p. 202) talks about this technique in the expression qobbe-ye separ bar sar čăšni nemudan [to place the shield buckles on/above the head].

d) Defending a downward vertical strike and grabbing the lance/spear: This technique included defending against a vertical spear strike by covering the head with a shield, grabbing the lance shaft with the left hand [note that Persian shields have two fabric or leather cords on the back of the shield which are held in the middle of the hand. Thus, this allows the shield bearer to grab the lance or even the wrist of the opponent], pulling it and disarming the opponent as described in the manuscript Dārābāme [Book of Dārāb] (Beyqami, 2002, vol. 2, p. 179) with the expression separ bar sar kešidan dast az zir-e separ birun kardan va sar-e senān rā gereftan va az kaf birun kardan [to protect the top of the head with the shield, to bring out the [other] hand below the shield, to get hold of the spearhead [of the opponent], and to pull it out of his hand].

e) Defending the shoulder against a vertical sword strike: By placing the shield over the shoulder one could defend this area as described by the Digital Lexicon of Dehxoda with the expression separ bar ketf duxtan [lit. to sew the shield on the shoulder; to raise the shield above the shoulder].

f) Defending the side of the body against a horizontal sword strike: To defend the sides of the body against a horizontal sword strike, one used the technique separ be samt gardandan or separ gardāndan [to turn the shield to the side or to turn the shield] as described in the 11th-century manuscript Samak Ayyār (al-Kāteb al-Rajāni, 2004, pp. 917 \& 1281). One could also use this technique in combinations as well, or against a spear/lance or arrow strikes after these had hit the shield surface. After the strike, one brought the shield forward separ jolo a vardan [to place the 
shield in front] and then turned the shield so that the spear/lance head could not penetrate the shield deeply. This technique is called separ be samt gardāndan or separ gardāndan [to turn the shield to the side or to turn the shield] (al-Kāteb al-Rajāni, 2004, pp. 917 \& 1281). In the following the application of this technique is described (al-Kāteb al-Rajāni, 2004, p. 917):

All of a sudden, he found an opportunity and attacked the chest of Hormozakil with his spear. Hormozakil brought his shield to his front. Like the needle of a master tailor that pierces the silk fabric, the spear pierced his shield to throw the fire of death in the body of the champion; however, Hormozakil who was war-experienced and had learned many skills, turned his shield to the side and the spear did not reach his chest, but the tip of the spear hit the arms of the champion and injured him.

g) Turning the shield and striking the sword hand [of the opponent]: One used a shield to defend against a downward vertical strike and then turned this to push down the sword/weapon of the opponent and create an opening in the opponent's guard to attack the opponent's arm/wrist with a counter sword strike as reported in the manuscript Širuye Nāmdār [The Famed Širu] (2005, p. 401) with the expression separ be čarx andāxtan va bā šamšir bar band-e dast navāxtan [to turn the shield [after it was used to defend against a vertical strike to the head] and to hit the wrist [of the opponent] with a sword].

h) Spinning the shield above the head: Another technique is spinning the shield above the head so that the sword strikes would glide on the shield surface and not be able to cut the surface of the shield as described by the Šahanšahnāme [Book of King of Kings] with the expression separ be sar čarx kardan [to spin the shield above the head] (Sabā, undated handwritten manuscript, p. 110).

i) Defending the face against the strikes: With positioning the shield in front of the face, one could defend his face against incoming sword strikes as described in the 14th-century manuscript Zafarnāme [Book of Victories] with the expression separ dar ruy kešidan [to pull the shield in front of the face] (Yazdi, 1957, p. 480). This technique is also mentioned in the manuscript Siruye Nāmdār [The Famed Širu] (2005, p. 78) with the expression separ rā az ketf nejāt dādan va dar piš ruy-e xod gereftan [to save [to get out] the shield from the shoulder and to hold it in front of the face/front].

j) Defending the body against sword strikes: Covering the body against horizontal strikes or thrusts is mentioned in the Romuz-e Hamze [Secrets of Hamze collected in the second half of the 15 century] (1940, p. 60) in the expression tan be zir-e abr-e separ penhān kardan [lit. to hide the body below the cloud of a shield; a defensive move using a shield to defend the body].

k) Using two hands for holding the shield against strong strikes: Some Persian manuscripts refer to the use of two hands for holding a shield against very heavy downward vertical strikes. The 15th-century manuscript Dārābnāme [Book of Dārāb] presents this technique as separ dar sar kešidan va har do dast rā sotun-e separ kardan [to pull the shield above the head and to use both hands to hold the shield] (Hakim, unspecified date, p. 551).

\subsection{Using the armguard as a shield}

Persian manuscripts also report about the active use of the bāzuband/sāedband (armguard) to defend oneself against sword strikes as mentioned in the 12th-century manuscript Eskandarnāme [Book of Eskandar] with the expression sāedband be dam-e šamšir dādan [lit. to give the armguard at the edge of the sword] (Hakim, unspecified date, p. 551). This technique consisted in defending oneself against a sword strike by positioning the armguard in the arc of the opponent's sword. This technique was especially used when the shield was broken/torn or when there was no other way but to use the armguard for the last resort defense (see Romuz-e Hamze [Secrets of Hamze collected in the second half of the 15 century], 1940, pp. $272 \& 380$ ). Persian manuscripts report that at times one could have the opponent's sword broken after the application of this technique (see Romuz-e Hamze [Secrets of Hamze collected in the second half of the 15 century], 1940, p. 413). The manuscript ŠiruyeNämdār [The Famed Širu] (2005, p. 78) describes this technique as sāedband bar dam-e tiq zadan [to give the armguard at the edge of the blade]. 


\section{Indian swordsmanship}

Swordsmanship traditions in North India and corresponding traditions of teaching these skills have a mixed character. This region used to serve as a corridor or a gateway to India for new invaders who, on the one hand, brought their own culture and traditions and on the other hand this region turned into a melting pot for mixing different traditions. A type of melting pot which discarded every ineffective moves and techniques and retained the most practical and efficient ones. For these reasons it is very hard to determine exactly nowadays, which practices are of indigenous Indian origin, which practices were introduced by later conquerors, and which of them occurred as a result of different mixture of foreign and indigenous traditions. However, some differentiation is necessary for studying and understanding North India swordsmanship traditions, and this can be done based on the following components. Firstly, the Mogul aristocracy traditions which represent the most widely spread and well-documented written sources describe some practices. Since the martial arts which were under the Moghul patronage basically correspond with the military practices spread in Muslim sultanates of Central India. Taking into account that the Deccan sultanates were established on the ruins of the Delhi Sultanate, it is possible to assume that these practices were already introduced by the conquerors in the 13th century and that they are of either Persian or common Central Asian origin influence.

It is reasonable to assume that these practices are of purely Persian origin and that they were spread throughout the Muslim world with an increasing Persian cultural influence. The second assumption is more likely to be true because at the beginning of the 11th century the best representatives of the Persian culture found shelter at the court of Mahmud Ghaznavid, who invaded North India several times. However, it would not be entirely correct to consider these practices to be purely «Persian», because although this tradition had Iranian roots it had been evolving in isolation from its parent culture, and was also surely influenced by the Indian environment. An indirect confirmation of this is found in a treatise about the swords Resāleh-e Šamširšenāsi [Treatise on Swordsmanship] composed by Nusrat al-Iāh Khān in 1706 which contains Indian terminology (see Marshall, 1985, p. 273). Also the treatise on the art of archery Usul-e Qabze [Principles of the Bow Grasping] composed by Abu Hisam al-Din Muhammad in 1624 contains numerous words in both Turkic and Hindi (Sprenger, 1896, p. 30). Thus, when one assumes a possible Persian origin of these practices and their interaction as a substrate with a superstratum of local Indian culture, there is a reason to define these practices as "Moghul" in accordance with the fact that the Moghul culture was actually Indo-Persian. This definition is further confirmed by the fact that these practices became widely spread exactly during the period and in the territory of Moghul Empire, as well as they were a part of military training in the Moghul army (Irvine, 1903, pp. 185-186). Through this process they gradually became commonly accepted among the people, and continued their existence as a sport of soldiers in the British Indian Army until the end of the 19th century (see The Illustrated London News, July 13, 1878, "The Indian Troops at Malta", p. 27). Of course there is a difference between the art of sword fighting, which was popular among the dignitaries in the 17th century, and exercises which were for the entertainment of soldiers in the end of the 19th century. Illustrations from the manuscript Nihangnama [Book of Nihangs], composed in Ahmadnagar in the early 17th century, show a serious, martial attitude towards this art, unlike later practices (see Picture 6).

Mogul practices can be distinguished both by technical differences and also by the terminology used in the Persian language. It is hard to assume that practices, which were under patronage at the courts of Akbar and Muslim sultanates of Central India, were of Dravidian or Rajput origin. There is another evidence in favor of a significant Persian component, which is that there were numerous texts of Persian origin about archery, swordsmanship, stick and staff games etc. in the Lucknow library in the end of the 19th century (Sprenger, 1896, p. 17). The Moghul line was aristocratic in character, since the highest state leaders either practiced this art themselves or were direct patrons of the best fighters (Nur-ud-din Mohammad Salim, 1909, pp. 253 \& 335). Famous swordsmen and wrestlers traveled around the country, offering their services as mentors at the courts of the rulers, and preferred to avoid students with plebeian origin. Their target audience consisted of aristocrats and, primarily, their sons, whose education was aimed to be developed in two traditional directions: "the pen and the sword" (Blake, 2002, pp. 146-149). Masters were also employed for the preparation and training of the military forces. In the Moghul 
army, generals paid less attention to the tactical coordination of the military units on the battlefield. Moreover, they devoted much time to the physical training of the body and the individual dexterity in handling different kinds of weapons. This way, the trained and explored techniques became popular among soldiers and were spread later through the whole population. Gradually with changing nature of the warfare and corresponding training methods, the aristocratic martial practices ceased to exist. Over time they degraded to the level of sport games among the soldiers, and they continued to exist in a modified form among the general population where close-in fighting skills remained popular for a long time (see Picture 7).

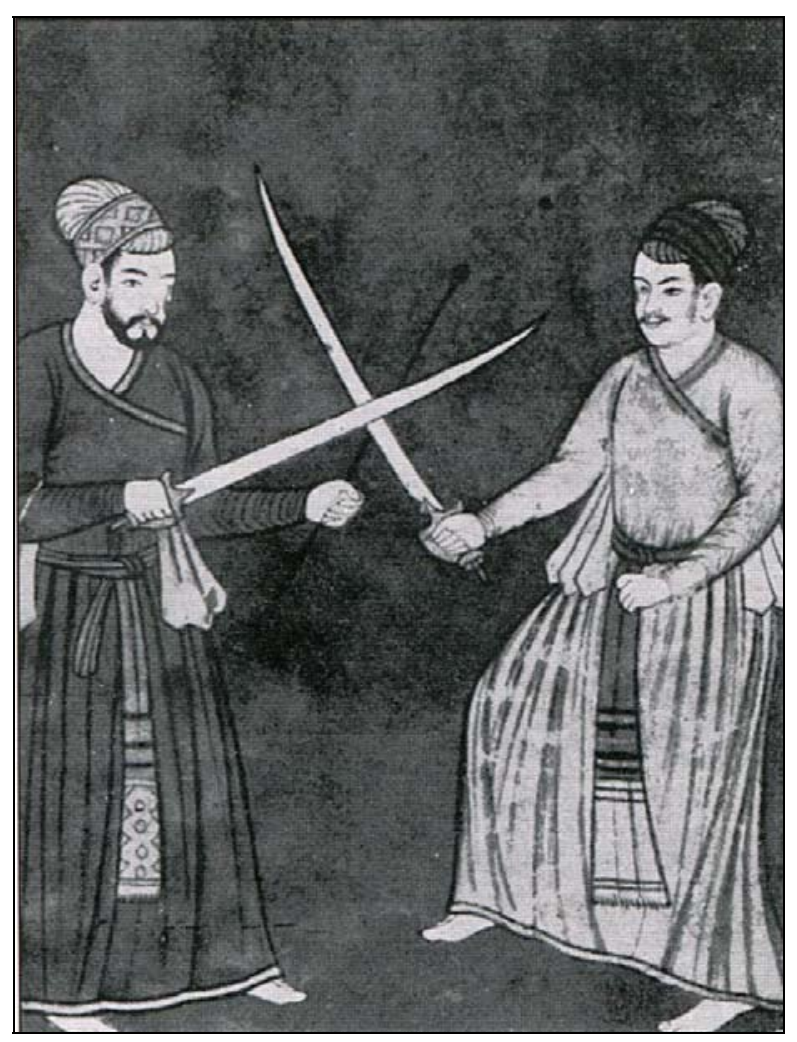

Picture 6. Illustration from the manuscript Nihangnama, Ahmadnagar, early 17 th century.

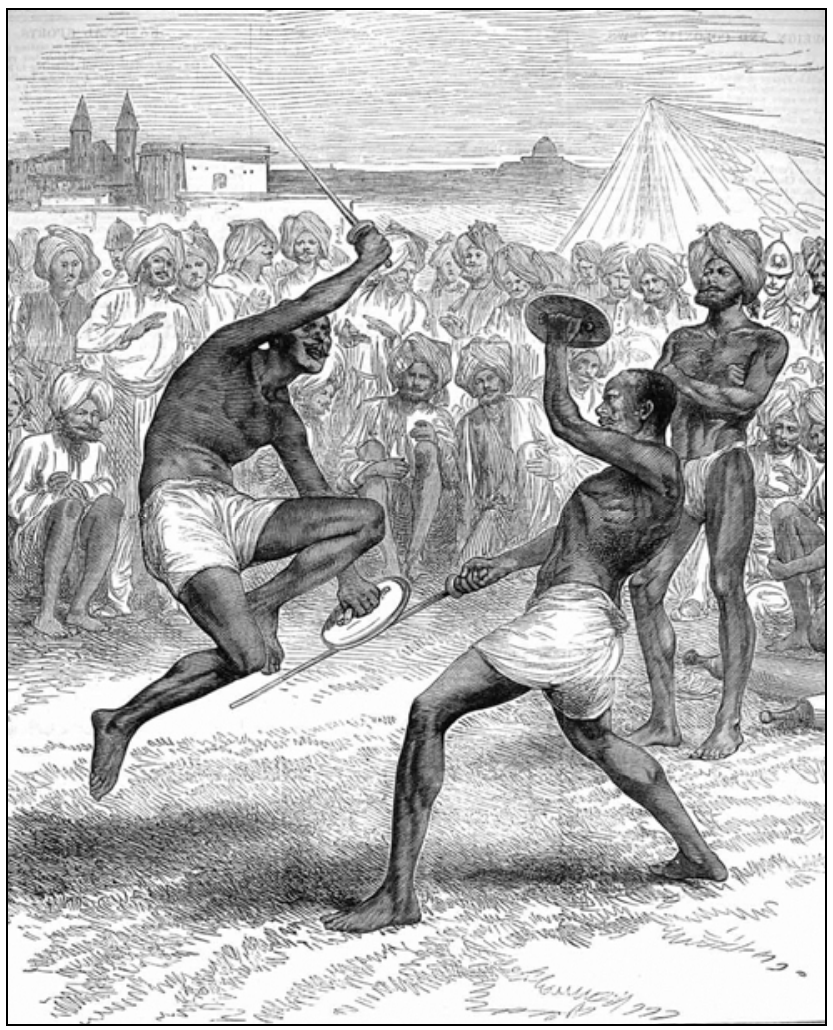

Picture 7. "Indian soldiers' games”. The Illustrated London News, July 13, 1878.

An approximate description of traditional Mogul combat could be based on descriptions of the practices at the Mogul court, the Ahmednagar Sultanate, as well as of numerous descriptions of soldiers exercises and entertainment. This information is available thanks to the Persian historian Mohammad Qāsem Hindu Shāh, who served as a captain of the personal guards at the Ahmednagar court at the end of the 16th century, and later lived at the Bijapur court. Due to him, we know that military practices were already widely spread in Bahmanid Sultanate. After its collapse in the early 16th century they did not disappear, but became even more widely spread in the newly formed Deccan sultanates (see Mohammad Qāsim, 1910, pp. 207-208). Mohammad Qāsim Hindu Shāh described that "Burkham Nizam Shāh the First, the ruler of Ahmadnagar Sultanate, was fascinated by military practices and devoted much time to these exercises". It is natural that a lot of followers and imitators appeared which led to the establishment of many martial arts schools in every Ahmadnagar quarter, so that their total number equalled or surpassed the number of madrassas [a specific type of religious school or college for the study of the Islamic religion]. Gradually the palace became the place for daily duels between dozens of swordsmen, where they demonstrated their skills, and each day, one or two men were killed. In time, the court duels were banned, and masters of the sword moved to the countryside to compete in their skills. Initially this practice was recognized as legitimate; the murder in a duel was considered honorable and did not have any subsequent consequences. This phenomenon spread beyond Ahmednagar's borders, and the practice of settling the disputes in form of duels also reached aristocratic society, including philosophers and theologians. Anyone who could not stand up for himself in such a duel was 
blamed for his lack of spirit and courage. It is necessary to describe the following practices which existed at the time and are directly related to fencing techniques. There are numerous techniques emphasizing the use of a small shield in combination with a wooden stick representing a sword. The stick often had a guard supported by leather or fabric to protect the hand and to soften the impact force of the opponent's strikes. "Yekung bazy" is when the sword or stick alone is used. "Doung bazy" is when the shield, or two swords are wielded, one in each hand (see Mohammad Qāsim, 1910, pp. 207-208) (see Picture 8).

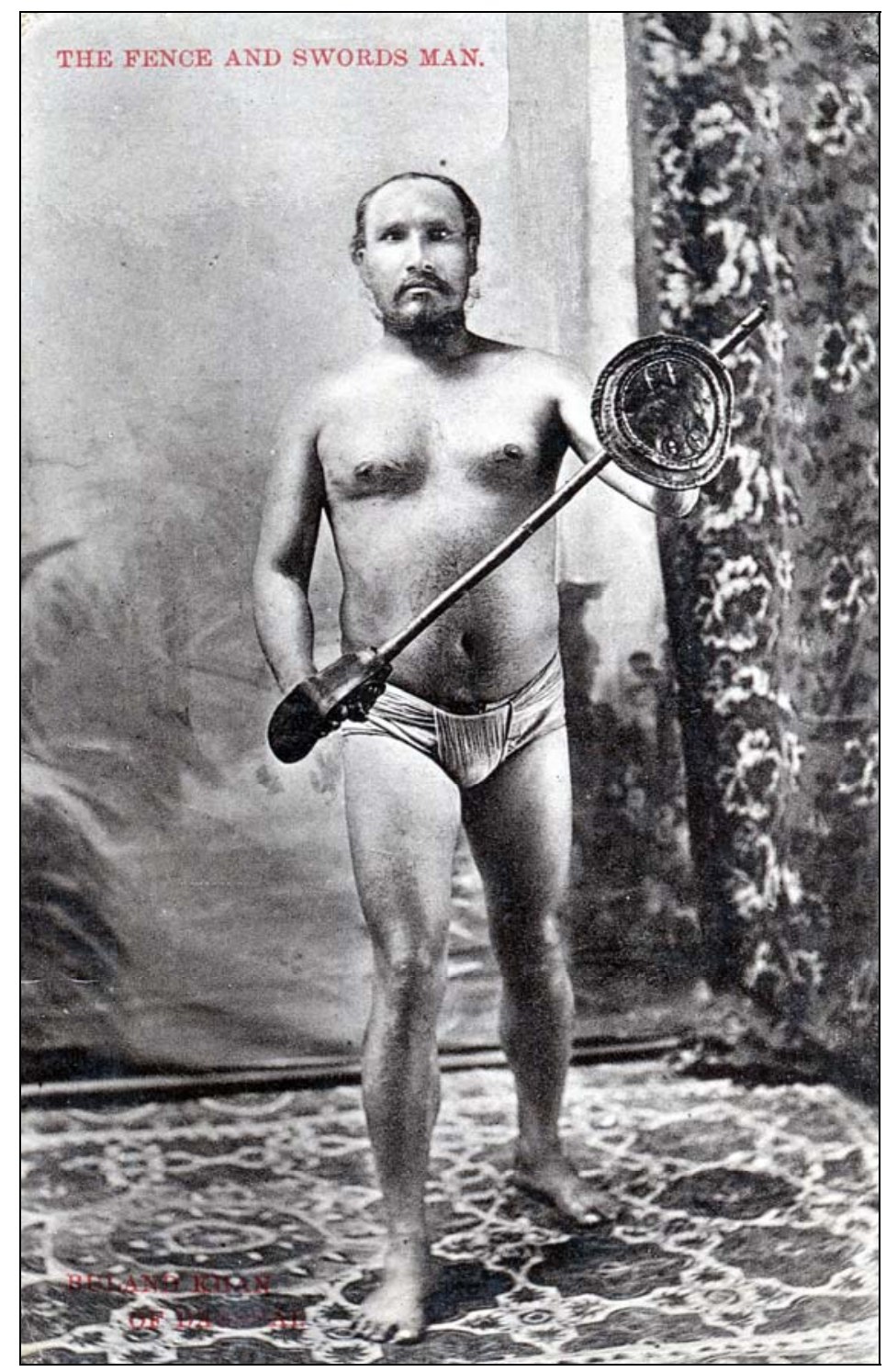

Picture 8. Indian fencer.

Using this combination, a shield served as an exclusive means of protection and parry. Although, some protection techniques included a combined use of the shield and stick. The stick was used for cutting strikes, as well as for thrusting. This technique like all other Indian techniques contained a large number of feints and attacks to the legs and, particularly, attack to the the feet. For instance, one of the techniques included feinting a head strike and then moving to strike the foot instead (Mundy, 1832, pp. 280-281). Two-handed sword techniques existed until the middle of the 19th century, but nowadays we know only little about them. It is said in Ayeen Akberi [Institutes of the Emperor Akber] that Akber's army included units of soldiers who were armed with twohanded swords with handles more than half a meter in length (Ayeen Akbery [The Institutes of the Emperor Akber], 1800) (see Picture 9). Abdul Halim Sharar was an essayist and historian of Lucknow, and describes many of the practices that existed in Lucknow in the first half of the 19th century. Among them there was a type of dagger fighting called bank;binaut, which was a skill of 
disarming the opponent from his sword, staff or whatever he holds; and arts of pata hilana. All researchers agree with Sharar that pata hilana was a type of fencing with a wooden sword. However, it is known that such terms as patebaz or patait mean "swordsmanship". The term khilana means "to play". Therefore, pata hilana is more likely to mean "swordplay". Of course, both, a wooden sword or a stick, surely could be used in these swordsmanship practices. Also Sharar's descriptions contain information about using of a sword pata (a straight, double-edged sword with a gauntlet). There are known descriptions of techniques with sword and shield, as well as with two swords simultaneously holding one in each hand (Sharar, 1994, pp. 110-111).

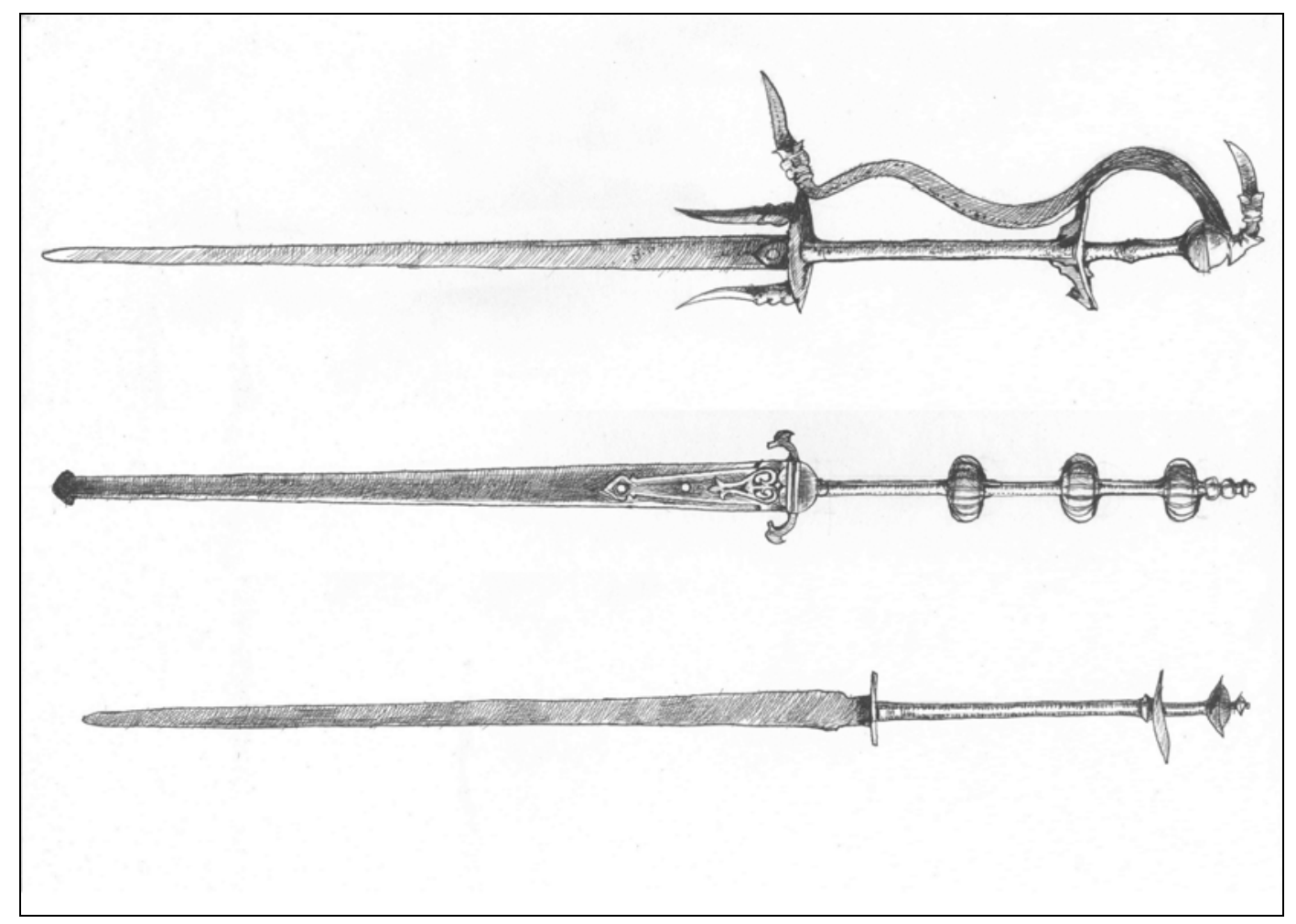

Picture 9. Some examples of two-handed Indian swords.

Unfortunately, these exercises were only used for sport and entertainment during the Moghul period and these practices did not play a role in the individual training of the warrior. Also the British administration eliminated real martial practices after the Sepoy Rebellion. Generally, a reduced interest in national fighting traditions in the later period also affected these activities negatively. There is a second component of these activities, which according to reliable sources, is not of a purely Indian origin (Kurochkin, 2014). It was a synthesis of the Muslim aristocracy practices with Indian practices, which were probably based on indigenous Dravidian traditions. This system developed within the traditions of warriors-ascetics, whose range of interests included the use of military practices for spiritual development, the protection of their communities, as well as mercenary military service, collecting indemnities and sometimes plain banditry. By the time of the Muslim invasion, a tradition of warriors-ascetics had already existed in India. There is a description of an episode in Akbarnāme that Akbar personally witnessed an armed fight in Thanesare between yogis for a place at the holy pond, using bows and arrows, throwing steel rings chakram, swords and other cold weapons (see the picture "A battle between sannyasis at Thanesar in north-west India, watched by the Mughal emperor Akbar", 1586-1589, Victoria and Albert Museum, IS.2: 61-1896). According to oral tradition, Akbar legalized the practice of creating ascetics' militias. The permission was granted to them in response to the ascetics' leaders appeal about the necessity of self-defense against Muslim ascetics' outrage (Farquhar, 1925, p. 442). Akbar's religious liberalism influenced his decision, which subsequently let the genie out of the bottle, and ascetics started to recruit not only members of the Brahmin caste but also other Indians into their ranks, develop a network akharas (a network of training schools) and create armed groups. It is necessary to note that the ascetics in India acted similarly as European military orders, 
such as the famed Knights Templar, in the sense of becoming religious military bodies that also accumulated great wealth such as precious stones, and did a lot of trade. Gradually mercenary business was also added to this list. As a result by the 18th century, one can see the ascetics transformation from the armed yogis' gangs of the 16th century to the troops of trained mercenaries, using muskets and cavalry. But even at a later time they were considered to be excellent masters of close-quarters combat, especially, with a sword, thus they were used as a shock infantry (Pinch, 2006, pp. 70-82).

Unluckily it is hardly possible to determine the precise origin and ethnicity of military practices of the region. The militarization degree of the population of the region was an unprecedented event when peasants were recruited by means of mercenary military service at the end of the agricultural season. They could be considered as accomplished soldiers in terms of their individual military training as both sword training and military skills training generally started during childhood. At the same time, for example, Rajputs had no restrictions for girls and women. Earl Egerton, Lord Tatton, collector, traveler and explorer of India noted: "The Rajputs are all brought up to the use of arms. Every village has its gymnasium where instruction is given morning and evening in the use of weapon and the practice of athletic exercises and these must have contributed much to their martial bearing and soldierly qualities" (Egerton, 1896, p. 105). It is also reported that men did not leave their village without a sword, a shield, a bow and arrows already in the early 19th century, as well as without a long spear and a saddle axe if they had a horse (Heber, 1843, p. 110). They worked in the fields with a shield behind and a sword on the side during the Sepoy Rebellion in the middle of the 19th century. A high degree of militarization was common in the entire region, especially among Rajputs, Jats, Gujarati and Marathi as well as a high mobility of the population. It is also impossible to define these practices as purely "Indian" as some borrowing must have taken place from aristocratic Muslim practices, as mentioned before. These practices could conventionally be defined as "folk" military practices that existed in the region within the framework of traditional Indian schools Akhara. Thanks to practices preserved to the present, it is possible to carry out some analysis and to identify some characteristics that separate this folk practice from other military traditions of North India.

A specific style of footwork makes up the root of these techniques, which was common for all North Indian techniques and is known as pentra, petra or pantra. There is nothing difficult in the movement itself, while the main goal is to exhibit a moving skill through the movement of the legs and thighs. It sounds strange, since any person moves through the movement of the legs and thighs, but not everyone is able to simultaneously strike and defend with a saber or two sabers parallel to random changing of the moving direction, the angles of attack and defense, rhythm and distance, without stopping, freezing or stumbling. By correctly exhibiting this technique of moving, a trained fighter is able to react to a threat from any side. This is the most important skill when participating in a group fight, where the danger of an attack from the side or from behind is the most likely. Existing descriptions of battles during the Sepoy Rebellion show that in majority of cases the most dangerous place to be killed or to be wounded was not where the enemy who stood directly in front of a fighter. Exhibiting this technique properly is even more important for a young and inexperienced warrior. This movement is mentioned quite often in the memoirs of British officers that while engaging in the fight, the Indians began to move in a strange way, "to dance" (Spilsbury, 2008, p. 270).

The next extremely important skill prior to obtaining proficiency with a saber is a skill of wielding the staff. Although spinning the staff at first glance seems to be useless for any real application, it builds coordination, strengthens the grip and provides a basis of motion, as the momentum of the staff needs a response from the body of the fighter. This technique works only if the staff is fully held with the hands and if all fingers hold the staff firmly, especially the third and little fingers. Weakening the grip of the staff turns an exercise into juggling. By exhibiting the correct staff techniques combined with moving, coinciding in cycles with movements of arms and legs, one can eventually develop skills of controlling the hand by twisting the thighs, back and shoulder muscles. This set of combined techniques was described as Indians threw the whole force of their body into the blow. The sword techniques were executed with a bent elbow holding the sword and the arm was never completely straightened. The hand holding the stick or the saber is kept tightly but at the same time allowing the weapon to move freely while transmitting the power 
to the weapon in hand. The technique resulted in a type of strike known as "draw cut" or a "slicing cut".

Here one should dispel another myth about the theory tha tulwars handles are small because of supposedly small-sized hands of small Indians, which is commonly assumed among some European and American collectors. North-West and Central Indians are only slightly different in size from Europeans. There are also talwars with quite big and adequate handles in Rajasthan museums with collections stemming from palace arsenals. One should take into consideration the militarization degree of the inhabitants from these regions of India, as well as the degree of womens' and childrens' involvement in military training which indicate the existence of really small-sized sabers and their corresponding handles. There will be some discomfort feeling for the untrained hand during the exercises with a tulwar, including the hand's skin worn-off in places of contact with crossing section or handle's disk. All inconveniences disappear after holding the handle of a tulwar correctly. Besides the main limiting function, also the presence of the disk-like hilt gives extra support for the fist to make a reverse pulling movement. With this kind of hilt it is nearly impossible to make any kind of cut except one in which the edge leads (Thomson, 1893, $p$. 38). Such techniques of swordsmanship require a similar change even in handle design of shamshirs (Picture 10).

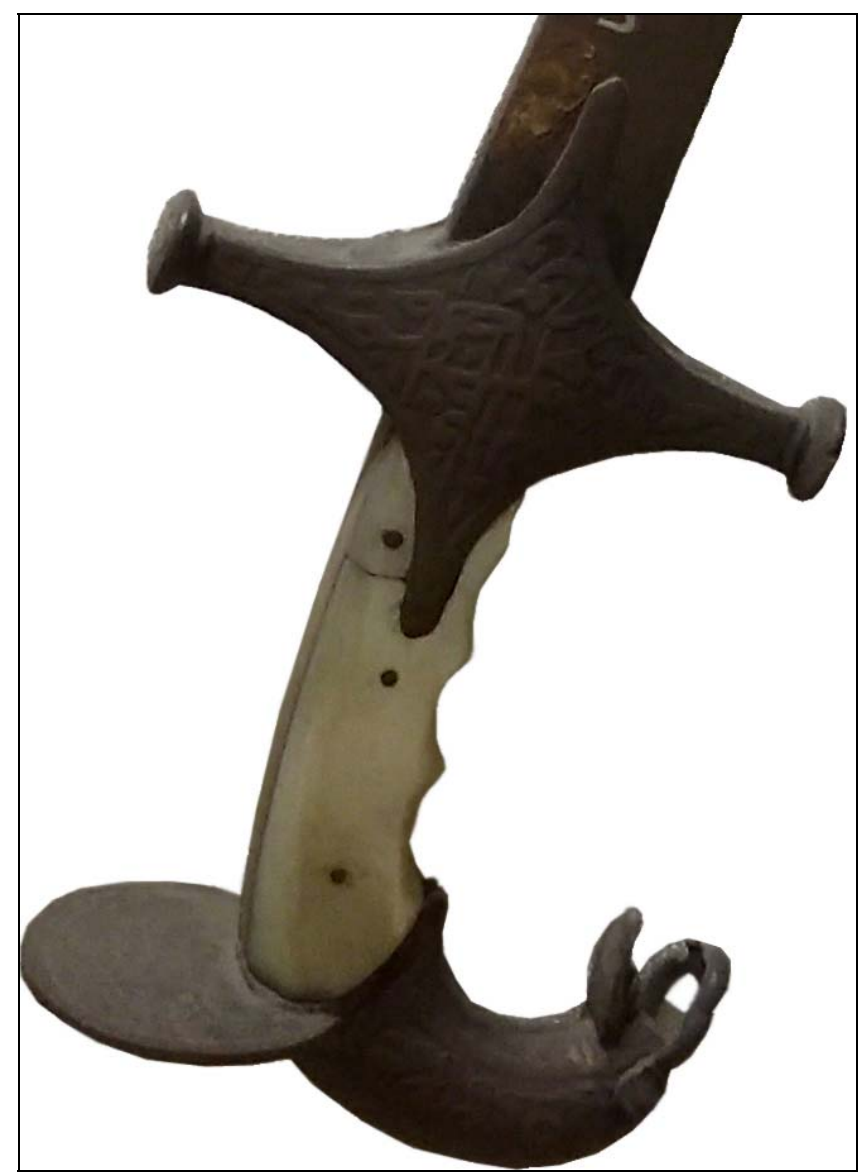

Picture 10. The handle of a shamshir with a disc.

Since it is possible to strike heavily even with a stick, we will leave aside numerous descriptions of the power of Indian blows and will give descriptions of the damages inflicted by cutting strikes. Firstly, the British surgeons emphasized the lack of any compression signs. The cut was always clean, thin and without extra noticeable damages, while the wounds after the Europeans customary strikes contained compression signs, breaks and other accompanying injury. The tulwar strike cut off the limb completely, or cut to the bone at least (Stevenson, 1898, p. 3). It happened often that the injured man even did not feel the pain caused by the damage immediately. One strike could cut off the head, both hands, the hand and the shoulder with a body part or both 
legs. The Europeans could split the enemy's skull in half with a powerful direct downing strike. The Indians achieved the same result by means of delicate cutting strike with the use of ingenuity and mastership instead of brutal force. The Indians managed their tulwars so easily, that the British compared the process with the use of a whip or a stick. The strikes' performance and its result influenced the tactics of its application. Cutting-off the limbs was the main method. When fighting on foot, the weapon hand and forward leg were attacked first. The last mentioned method was favored to that extent so that the British put their legs forward intentionally provoking the attack of the Indians and to counterattack. Up to that point the Indians had been taught to attack the standing forward leg at all times. Other targets included the enemies' hand holding the saber, the hand holding the reins or the reins themselves.

The lack of obvious wide arcs in preparation for cuts caused the increase of passive protection, as the Indian warrior was almost always in a closed position during the fighting. The existence of the reverse cutting phase of the movement in the strike's trajectory returned the saber in the standby position for an active defense and the subsequent strike. The above mentioned acquired skill of spinning the staff caused a completely different effect in case of using weapons with a different construction for example when using the sword Khanda, which is as common as tulwar saber. As a rule, large, powerful models of this weapon are equipped with a spike on top of the hilt. The purpose of the spike is the opportunity to hold the sword also with the second hand. Many people think that holding a sword in such a manner is extremely inconvenient meaning holding a heavy sword with the second hand using a small spike on top of the handle. In fact, the balance of the khanda is strongly balanced towards the point, and corresponds with the balance of a wooden staff which is held at one end. Adding the second hand to hold the spike of a khanda or another sword with a forward center of gravity allows the swordsman to shift the center of rotation near the handle and to strike by means of familiar staff technique (see Picture 11).

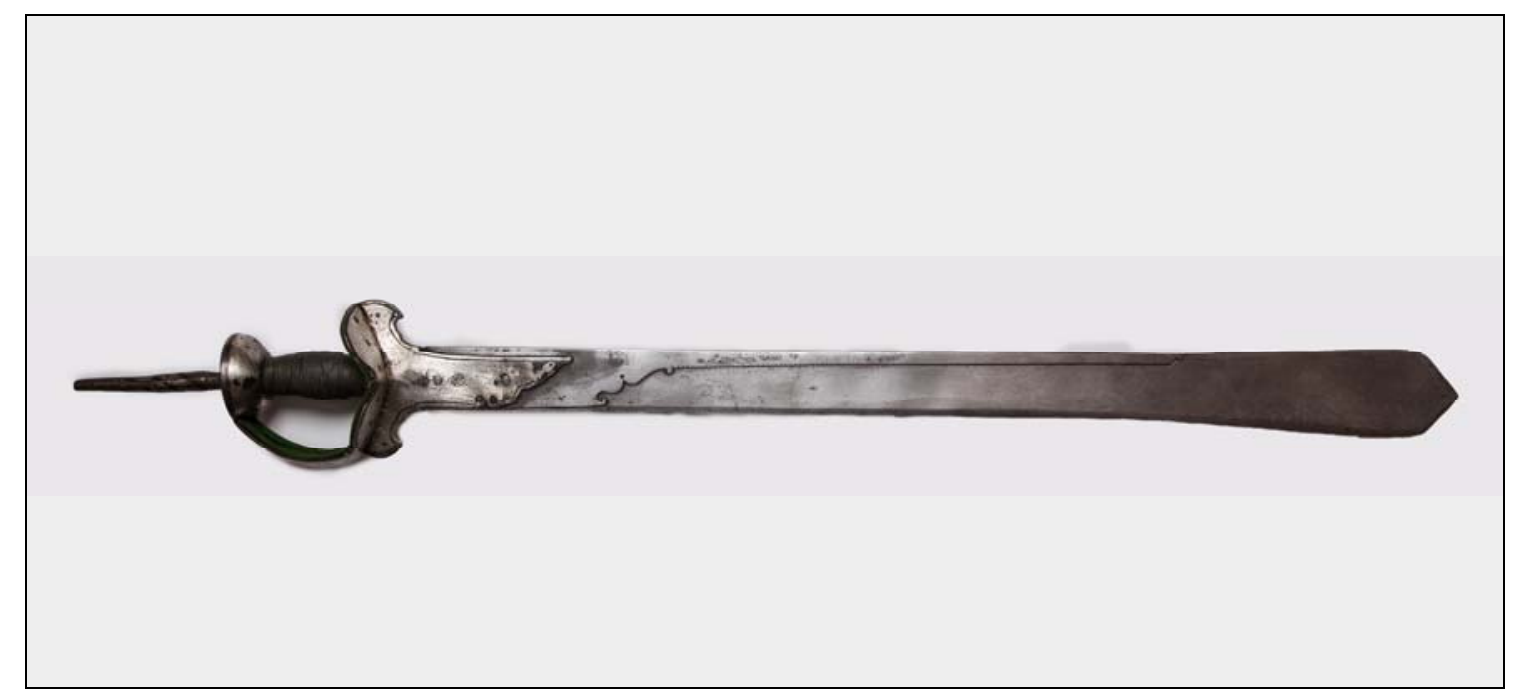

Picture 11. The sword khanda with a spike on the handle.

Real practices of using a shield that could be directly related to the battlefield techniques have not been preserved. According to the descriptions of witnesses, during the battle Indians took a bayonet strike on the shield and applied counter attacking as horizontal strikes above or below the shield. A shield was strapped behind the back often, especially when carried by horsemen. Besides it should be noted that the shield was not a significant advantage in the battle, and there are reports by British officers who stated that the use of a shield in combination with a sword by the Indian swordsmen was not a serious problem for their opponents, unlike the combination of a shield and a spear. Also the descriptions show that outstanding Indian warriors did not use shields at all. This is due to an Indian school of fighting which recommends that a shield should be only used as a defense against projectile weapons. Nevertheless, Indian soldiers used shields extensively in the 19th century and this can be explained by a century-old tradition. There are also reports on the simultaneous use of two swords in the real battle both by infantry soldiers and also by 
horsemen. The training curriculum was maximally aimed at the acquisition of combat skills with weapons. This could be proved by exceptionally high skills of Indian warriors in handling the saber during the Sepoy Rebellion (Kinsley, 2012, pp. 184-186).

\section{Conclusions: Similarities and differences related to techniques of swordsmanship}

The following conclusions can be formulated after comparing preserved data about Persian and North-Indian swordsmanship systems. Information about Persian system was preserved to the present day mainly in form of manuscripts, primarily prepared for the aristocracy and, consequently, for professional warriors. That is why techniques described in them focused on fighting armored opponents. In this case techniques were aimed not at applying of one lethal strike, but at the consequent actions, reducing the enemy's readiness and ability to perform effective attacking and defending. There were different types of weapons in the professional warrior's arsenal, which allowed eliminating the opponent in various ways, including a final fight with the use of short-bladed weapons. In the arsenal of North Indian practices there is noticeable emphasis on the coordination of the legs, ease of their moving and synchronization with the arms and the use of weapons. It is likely that these findings are influenced by the quality of preserved information which survived until now, the source of which are either sport entertainments, or training practices for ordinary people containing minimum military skills.

From this point of view and based on the compared data, which were obtained from the surviving sources, the two analyzed traditions have little in common. At least they show two completely different approaches to training methods and the acquisition of military skills. Perhaps, a possible obstacle preventing the finding of a common denominator is the fact that the North Indian tradition of military training, besides possessing authentic national differences, also experienced Turkic and Central Asian influences, and as Iranian influence was more indirect. Because of the similarity and uniformity of weapons, it is fair to speak about similar fighting methods, but only within the framework of a common central Asian military tradition, at least with the data available through the limited number of surviving and currently known sources. Future research will shed more light on the similarities and differences between Persian and North Indian fighting traditions.

\section{References}

\section{Primary sources}

Ālam Ārāye Šāh Tahmāsp [World Ornamentation of King Tahmāsp] (1991). Zendegāni-ye Dāstāni-ye Dovomin Padešăh-e Doreye Safavi [The Narrative Biography of the Second Safa. Edited and Annotated by Iraj Af̌̌ār. Tehrān: Entešārāt-e Donyāye Ketāb.

Āsef, M. H. (2003). Rostam al Tavārix: Salatin-e Selseleye Safaviye, Afšāriye, Zandiye va Qājāriye [Rostam al Tavārix: The Sultans of Safavid, Afšārid, Zand and Qājār]. Annotated by A. Alizādeh. Tehrān: Entešārāt-e Ferdos.

Al-Jāmi, M. (2001). Tārix-e Ahmad Šāhi [History of Ahmad Šāh]. Edited and commented by P. S. Homāyun. Pašāvar: Dāneš Xaparanduye Tulne.

Al-Kāteb al-Rajāni, F. (2004). Samak Ayyār. Annotated by Seyyed Ali Šahāri. 2 Vols. Tehrān: Sedāy-e Moāser.

Asadi Tusi, H. (1938). Garšāsbnāme [Letter of Garšāb]. Annotated by H. Yaqmā'i. Tehrān: Ketābforuši va Čāpxāne-ye Baruxim.

Ayeen Akbery [The Institutes of the Emperor Akber]. (1800). Translated by F. Gladwin, Vol. 1, London: O. Avld, Greville Street.

Beyhaqi Dabir, A. (2004). Tārix-e Beyhaqi [The Historyof Beyhaqi]. Annotated by A. Fayyāz. Mašhad: Danešgāh-e Ferdŏsi Mašhad.

Beyqami, M. M. (2002). Dārābnāme [Book of Dārāb]. Corrected and Annotated by Z. Safā. 2 Vols. Tehrān: Šerkat-e Entešārāt-e Elmi va Farhangi.

Dāstān-e Hosseyn Kord-e Šabestari [The Story of Hosseyn Kord-e Šabestari] (2003). Annotated by A. Šabgāhi Šabestari. Tehrān: Mo'aseseye Entešārāt-e Farahāni. 
Ferdŏsi, H. A. (2005). Šāhnāme Ferdŏsi (bar Asās-e Nosxeye Mašhur-ebe Čāp-pe Mosko) [Book of Kings byFerdŏsi (Based on the Manuscript Known as Published in Moscow)]. Tehrān: Entešārāte Alam.

Hakim, M. (Unspecified date). Koliyāt-e Haft Jeldi Eskandarnāme: Sāhebqarān Zowalqareneyn Eskandar ben Dārāb ben Bahman ben Esfandiyār Ru'intan [The Complete Seven Volumes of the Book of Alexander: Sāhebqarān Zowalgareneyn Alexander, the Son of Dārāb, the Son of Bahman, the Son of the Invulnerable Esfandiyār]. From the Series of Legends of Oriental Pahlavān. Tehrān: Entešārāt-e Mohammad Hasan Sar Elmi.

Kāšefi Sabzevāri, M. (1971). Fotovvatnāme-ye Soltāni [Royal Book/Letter of Chivalry]. Commented by Mohammad Ja'far Mahjub. Tehrān: Entešārāt- Bonyād-e Farhang-e Irān.

Mobārak Šāh Faxr-e Modabbar, M. (1967). Ādāb al-Harb va al-Šojā-e [The Customs of War and Bravery]. Annotated by A. Xānsāri. Tehrān: Eqbāl.

Mohammad Qāsim, H. Sh. (1910). History Rise of the Mahomedan Power in India till the Year A.D. 1612. Vol. III. Translated by J. Briggs. London: Kegan Paul, Trench, Trubner \& Co.

Mostufi, H. (1999). Zafarnāme be Enzemām-e Šāhnāme Abolqāsem Ferdŏsi [Book of Victories together with Book of Kings Abolqāsem Ferdŏsi]. With an Introduction by Dr. Nostratollāh Rastegār. Tehrān: Markaz-e Našr-e Dānešgāhi.

Nāderi, A. (1968). Zafarnāme [Book of Victories]. Introduction by M. Farrox. Tehrān: Entešārāt-e Ketābxāne-ye Melli-ye Mālek.

Nur-ud-din Mohammad Salim (1909). Tuzuk-i-Jahangiri or Memoirs of Jahangir. Translated by A. Rogers. London: London Royal Asiatic Society.

Rašidoldin Fazlollāh Hamedāni, A. (1985). Jāme-al Tavārix (Az Aqāz Peydayeš Moqol Ta Pāyān Doreye TeymurQ ā'ān) [The Complete History (From the Emergence of the Mongols until the End of the Era of Timur)] Written in 703 Hegira (1304 C.E.). Annotated by B. Karimi. Tehrān: Entešarat Eqbāl.

Romuz-e Hamze [Secrets of Hamze] (1940). Anonymous Author. Handwritten by Mohammad Ali Nāme. Tehrān: Šerkat-e Tab-e Ketāb.

Sabā, F. Šahanšahnāme [Book of King of Kings]. Undated and Handwritten Manuscript. Mašhad: Āstān-e Qods-e Razavi.

Šabānkāre'i, M. (2002). Majma' al-Ansāb (Nimeye Avval) [Complete Collection of Peoples (First Part)]. Commented by Mir Hāšem Mohaddes. Tehrān: Entešārāt-e Amir Kabir.

Širuye Nāmdār [The Famed Širu] (2005). Anonymous Author. Tehrān: Entešārāt-e Qoqnos.

Tartusi, A. T. (2001). Abu Moslemnāme [Book of Abu Moslem]. Annotated by H. Esmā'ili. 4 Vols. Tehrān: Entešārāt-e Moi'n, Našr-e Qatre, Anjoman-e Irānšenāsi dar Irān.

Xusofi Birjandi, H. (2002). Xāvarānnāme [Book of the East]. With an Introduction by S. Anvari. Tehrān: Sāzmān-e Čāp va Entešārāt.

Yazdi, M. Š. (1957). Zafarnāme (Tārix-e Umumi-ye Irān dar Doreye Teymuriyān) [Book of Victory (The General History of Iran during Timurid Period)]. Corrected and Annotated by Mohammad Abbāsi. Tehrān: Amir Kabir.

\section{Secondary sources}

Bahari, E. (1996) Bihzad: Master of Persian Painting. London \& New York: I. B. Tauris Publishers.

Blake, S. P. (2002). Shahjahanabad: The Sovereign City in Mughal India 1639-1739. Cambridge: Cambridge University Press.

Bosworth, C. E. (2004). The new Islamic Dynasties: A Chronological and Genealogical Manual. (2nd Ed.) Edinburgh: Edinburgh University Press.

Chardin, J. (1988). Travels in Persia 1673-1677. New York: Dover Publications.

Dehxodā, A. A. (2006). Digital Lexicon of Dehxodā . Tehran: University Press..

Egerton, W. (1896). Indian and Oriental Arms and Armour. London: W. H. Allen \& Co.

Falsafi, N. (1996). Zendegāni-ye Šāh Abbās [The Biography of Šāh Abbās]. 5 Vols. Tehrān: Čāpxāne-ye Mahārat.

Farquhar, J. N. (1925). The Fighting Ascetics of India, Bulletin of the John Rylands Library, 9, 431452.

Frye, R. N. (1989). The Golden Age of Persia. London: Butler \& Tanner Ltd.

Heber, R. (1843). Narrative of a Journey Through the Upper Provinces of India in 1824-5. Vol. II. London: John Murray. 
Irvine, W. (1903). The Army of the Indian Moghuls. London: Luzac \& Co.

Khorasani, M. M. (2006). Arms and Armor from Iran: The Bronze Age to the End of the Qajar Period. Tübingen: Legat Verlag.

Khorasani, M. M. (2009a). Las técnicas de la esgrima persa. Revista de Artes Marciales Asiáticas, $4(1), 20-49$.

Khorasani, M. M. (2009b). El combate con armas blancas cortas en la esgrima persa. Revista de Artes Marciales Asiáticas, 4(2), 38- 53.

Khorasani, M. M. (2010a). Lexicon of Arms and Armor from Iran. A Study of Symbols and Terminology. Tübingen: Legat Verlag.

Khorasani, M. M. (2010b). La lucha: una parte integral de las artes marciales de combate en Irán. Revista de Artes Marciales Asiáticas, 5(2), 64-76.

Khorasani, M.M. (2013). Persian Archery and Swordsmanship: Historical Martial Arts of Iran. Frankfurt am Main: Niloufar Books.

Kinsley, D. A. (2012). British Sword Fighting. Self Publication (Standard Copyright License).

Kolff, D. H. A. (2002). Naukar, Rajput, and Sepoy. The Ethnohistory of the Military Labour Market of Hindustan, 1450-1850. Cambridge: Cambridge University Press.

Kurochkin, А. Y. (2014). Курочкин А.Ю., «Холодное оружие в традиционной воинской подготовке в Индии в 1500-1800 годах». Война и оружие. Новые исследования и материалы. Труды Пятой Международной научно-практической конференции. 14-16 мая 2014 года, часть II, 478-488, ВИМАИВиВС, Санкт-Петербург, 2014 (Kurochkin A. "Cold weapons in traditional military practices in North India duering 1500-1800". "Warfare and weapons. New researches and materials". Materials of 5th International Science-practical conference. 14-16th May 2014, part II, 478-488, Military-Historical Museum of Artillery, Engineer and Signal Corps, Russia, St. Petersburg).

Luijendijk, D. H. (2006). Zoor Khane: History and Techniques of the Ancient Martial Arts of Iran. Boulder: Paladin Press.

Marshall, D. N. (1985). Mughals in India: A Bibliographical Survey of Manuscripts. London: Mansell Publishing.

Modarresi, Y., Sāmei, H., \& Safavi Mobarhen, Z. (1991). Farhang-e Estelāhāt-e 29) Doreye Qājār: Qošun va Nazmiye [The Lexicon of the Expressions of the QājärPeriod: Army and Military]. Tehrān: Daftar-e Pajuhešhāye Farhangi.

Munday, G. C. (1832). Pen and Pencil Sketches. Being the Journal of a Tour in India. Vol. II. London: John Murray.

Nitin, S. (2008). Mobility, Control and Criminality in Early Colonial India, 1760s-1850s. The Indian Economic and Social History Review, 45(1), 1-33

Pinch, W. R. (2006). Warrior Ascetic and Indian Empires. Cambridge: Cambridge University Press.

Rawson, P. S. (1967). The Indian Sword. Copenhagen: Danish Arms and Armour Society.

Sharar, A. H. (1994). Lucknow, the Last Phase of an Oriental Culture. Oxford: Oxford University Press. Spilsbury, J. (2008). The Indian Mutiny. London: Orion Publishing Co.

Sprenger, A. (1896). Report of the Researches into the Muhammadan Libraries of Lucknow. Calcutta: Office of the Superintendent of Government Printing.

Stevenson, W. F. (1898). Wounds in War. New York: W. Wood \& Company.

Thomson, N. D. (1893). The curved sword in the native cavalry. Journal of United Service Institution of India, XXII, 102.

\section{Author's biographical data}

Mr. Aleksey Kurochkin (Moscow, Russian Federation) is a lawyer educated in the Moscow State Industrial University. He has been studying and practising Burmese and Indian martial arts for over 26 years. He has been doing research on oriental arms and warfare of India, China and South-East Asia since 2007. He has written articles on traditional military practices in North India for many journals and constantly participates in conferences on the history of weapons. E-mail: kay al@mail.ru. 
Dr. Manouchehr Moshtagh Khorasani (Germany) has written five books (four related to arms and armor), co-authored one book, and 139 print articles on Persian arms and armor published in different journals across the world. His books include Persian Archery and Swordsmanship: The Historical Martial Arts of Iran, Lexicon of Arms and Armor from Iran: A Study of Symbols and Terminology (Winner of the World Book Prize of the Islamic Republic of Iran 2012), Antique Oriental and Arab Weapons and Armour: The Streshinskiy Collection, The Development of Controversies: From the Early Modern Period to Online Discussion Forums and Arms and Armor from Iran: The Bronze Age to the End of the Qajar Period (Winner of the World Book Prize of the Islamic Republic of Iran 2009). He is the founder and an active member of Razmafzar Organization dedicated to the study and academic research on historical Persian arms and armor and martial arts. E-mail: manouchehr@moshtaghkhorasani.com. 